\title{
Assessment of Endothelial and Microvascular Function in CKD: Older and Newer Techniques, Associated Risk Factors, and Relations with Outcomes
}

\author{
Marieta P. Theodorakopoulou Maria Schoina Pantelis Sarafidis \\ Department of Nephrology, Hippokration Hospital, Aristotle University of Thessaloniki, Thessaloniki, Greece
}

\section{Keywords}

Chronic kidney disease - Microvascular function ·

Endothelial dysfunction · Flow-mediated dilatation ·

Near-infrared spectroscopy

\begin{abstract}
Background: Endothelium is the inner cellular lining of the vessels that modulates multiple biological processes including vasomotor tone, permeability, inflammatory responses, hemostasis, and angiogenesis. Endothelial dysfunction, the basis of atherosclerosis, is characterized by an imbalance between endothelium-derived relaxing factors and endothelium-derived contracting factors. Summary: Starting from the semi-invasive venous occlusion plethysmography, several functional techniques have been developed to evaluate microvascular function and subsequently used in patients with CKD. Flow-mediated dilatation of the forearm is considered to be the "gold standard," while in the last years, novel, noninvasive methods such as laser speckle contrast imaging and near-infrared spectroscopy are scarcely used. Moreover, several circulating biomarkers of endothelial function have been used in studies in CKD patients. This review summarizes available functional methods and biochemical markers
\end{abstract}

karger@karger.com

(c) 2020 S. Karger AG, Basel

www.karger.com/ajn

Karger $\stackrel{2}{=}$ for the assessment of endothelial and microvascular function in CKD and discusses existing evidence on their associations with comorbid conditions and outcomes in this population. Key Messages: Accumulated evidence suggests that endothelial dysfunction occurs early in CKD and is associated with target organ damage, progression of renal injury, cardiovascular events, and mortality. Novel methods evaluating microvascular function can offer a detailed, real-time assessment of underlying phenomena and should be increasingly used to shed more light on the role of endothelial dysfunction on cardiovascular and renal disease progression in CKD.

(c) 2020 S. Karger AG, Basel

\section{Introduction}

The endothelium constitutes the inner cellular lining of blood and lymphatic vessels; there are different kinds of endothelial cells which differ considerably from one another in structure and function [1]. The endothelium plays a central role in multiple physiologic functions, including regulation of vasomotor tone, vascular permeability, leukocyte trafficking, hemostasis, angiogenesis, 
Table 1. Main advantages and limitations of the functional methods used to assess microvascular function

\begin{tabular}{|c|c|c|}
\hline VOP & $\begin{array}{l}\text { High reproducibility and validity } \\
\text { Assessment at rest and after local infusion of vasoactive } \\
\text { agents }\end{array}$ & $\begin{array}{l}\text { Semi-invasive } \\
\text { Indirect measure of blood flow (not absolute numbers) } \\
\text { Limited application in exercise } \\
\text { Time consuming }\end{array}$ \\
\hline FMD & $\begin{array}{l}\text { Simple, inexpensive } \\
\text { Strong correlation with coronary function } \\
\text { Many outcome studies } \\
\text { Best validated technique for assessment of conduit vessel } \\
\text { function }\end{array}$ & $\begin{array}{l}\text { High inter- and intraobserver variability } \\
\text { Poor reproducibility if not performed in a } \\
\text { standardized manner } \\
\text { Requires adherence to strict scanning protocols } \\
\text { Requires well-trained, experienced operators }\end{array}$ \\
\hline LDF & $\begin{array}{l}\text { Noninvasive, very simple } \\
\text { Capable of measuring blood flow continuously during } \\
\text { active exercise } \\
\text { Coupling with other techniques }\end{array}$ & $\begin{array}{l}\text { Relatively expensive equipment } \\
\text { Requires mastered operator for high accuracy and low } \\
\text { day-to-day variability } \\
\text { Extremely sensitive to movement artifacts }\end{array}$ \\
\hline $\begin{array}{l}\text { Arterial } \\
\text { glycocalyx } \\
\text { (functional) }\end{array}$ & $\begin{array}{l}\text { OPS and SDF } \\
\text { Simple, noninvasive } \\
\text { Painless and rapid } \\
\text { Are executed at bedside }\end{array}$ & $\begin{array}{l}\text { OPS and SDF } \\
\text { Indirect measures of glycocalyx }\end{array}$ \\
\hline LSCI & $\begin{array}{l}\text { Produces real-time image recording continuous changes } \\
\text { in blood flow } \\
\text { Noninvasive, simple }\end{array}$ & $\begin{array}{l}\text { Relatively expensive equipment } \\
\text { Requires mastered operator for high accuracy and low } \\
\text { day-to-day variability } \\
\text { Extremely sensitive to movement artifacts } \\
\text { No recordings in absolute flow units }\end{array}$ \\
\hline
\end{tabular}

FMD, flow-mediated dilatation; VOP, venous occlusion plethysmography; LDF, laser Doppler flowmetry; LSCI, laser speckle contrast imaging; NIRS, near-infrared spectroscopy; OPS, orthogonal polarization spectral; SDF, sidestream dark field.

and innate and adaptive immunity [1]. Endothelial dysfunction is characterized by an imbalance between agents with vasodilating, antimitogenic, and antithrombogenic properties (endothelium-derived relaxing factors) and agents with vasoconstricting, prothrombotic, and proliferative properties (endothelium-derived contracting factors) [2]. Reduced nitric oxide (NO) bioavailability is a hallmark of endothelial dysfunction; NO plays a major role in endothelial dysfunction and arterial remodeling by several mechanisms [3].
Chronic kidney disease (CKD) is a major issue of public health with an estimated prevalence of $14.5 \%$ [4]. Patients with CKD have 2-fold higher mortality rate than those without CKD; cardiovascular disease is the main cause of death in this population [5]. The risk of cardiovascular events rises exponentially with the progression to end-stage kidney disease (ESKD) [6], so that more than the half of deaths in these patients is attributed to cardiovascular disease [7]. Many traditional and nontraditional risk factors are thought to have a role in cardiovascular 
disease development in patients with CKD [8]. Among the latter, endothelial dysfunction occurs in the early stages of CKD, reflecting multifactorial endothelial injury from various factors including inflammation, hypertension, diabetes-associated factors, and uremic milieu [9]. Endothelial dysfunction is shown not only to contribute in the development of cardiovascular disease in this population [8] but also to CKD progression [10].

Starting from venous occlusion plethysmography (VOP), which was first described and used for many years as the "gold standard," several methods have been developed to evaluate microvascular function and have also been used in patients with CKD [11]. Flow-mediated dilatation (FMD) of the forearm is considered now to be the "gold standard," while in the last years, novel, noninvasive, and easily applicable methods such as near-infrared spectroscopy (NIRS) and laser speckle contrast imaging (LSCI) gain more and more ground. In this article, we present an overview of the currently used methods to assess microvascular and endothelial function in patients with CKD and discuss the existing evidence relevant to the associations of endothelial dysfunction with comorbid conditions and outcomes in this population with high burden of cardiovascular disease.

\section{Assessment of Endothelial Dysfunction in CKD: Functional Methods}

\section{Venous Occlusion Plethysmography}

VOP was the first semi-invasive technique used for the assessment of vascular function, but it is now rarely applied in clinical practice as it is semi-invasive and time consuming (Table 1) $[12,13]$. The main principle of this method is simple; at a period when venous drainage from a tissue is obstructed without affecting arterial outflow, changes in tissue volume are proportional to arterial inflow rate [14]. VOP is based on the use of automatically calibrated mercury-in-silastic strain gauges, which are placed at a circular manner around the limb under examination [12,15]. Typically, an inflation pressure of 40 $\mathrm{mm} \mathrm{Hg}$ for 10-s intervals, followed by $5 \mathrm{~s}$ of deflation with the limb positioned at heart level, allows for venous emptying with minor changes in arterial inflow $[12,15]$. Vessel responsiveness is evaluated by measurement of forearm volume changes in response to reactive hyperemia or infusion of vasoactive compounds (i.e., acetylcholine, nitroprusside, etc.) $[12,14]$. Endothelium-dependent vasodilation on forearm blood flow ( $\mathrm{mL} / \mathrm{min} / 100 \mathrm{~mL}$ tissue) is evaluated by infusion of endothelial agonists (i.e., ace- tylcholine, bradykinin, etc.), whereas endothelium-independent vasodilation by the infusion of direct smooth muscle relaxing factors (i.e., nitrates) [14]. The main advantages and limitations of VOP and the other techniques discussed herein are presented in Table 1.

In previous studies in patients with $\mathrm{CKD}$, Passauer et al. [16] showed that endothelium-dependent vasodilation assessed with VOP was reduced in hemodialysis patients compared to controls, but it was improved after renal transplantation [17]. This impaired endothelial function in ESKD was associated with traditional risk factors, such as increasing age and the presence of diabetes mellitus (DM) [18], but also with duration of ESKD, cardiac and arterial remodeling, and other nontraditional uremia-associated risk factors $[19,20]$. In 44 patients with CKD stage 3-5, endothelial dysfunction assessed by VOP was correlated with oxidative stress but was independent from C-reactive protein (CRP) levels [21].

Furthermore, London et al. [22] studied 78 hemodialysis patients and found that decreased postocclusion forearm reactive hyperemia was associated with all-cause mortality, independently of the presence of LV hypertrophy (LVH) or arterial stiffness (Table 2). Perticone et al. [23] studied 500 treatment-naïve uncomplicated hypertensive patients in order to assess the role of endothelial dysfunction in the progression of CKD and demonstrated that acetylcholine-stimulated vasodilation and SBP were associated with estimated glomerular filtration rate (eGFR) loss after adjustment for other cardiovascular risk factors and antihypertensive treatment during a $92 \pm$ 36-month follow-up. Last but not least, long-term therapy with amlodipine and/or renin-angiotensin-system inhibitors significantly decreased forearm resistance measured by VOP compared to metoprolol treatment in patients with advanced CKD [24]. Similar results were observed in another randomized study using low-dose spironolactone versus placebo in hemodialysis patients without heart failure [25].

\section{Flow-Mediated Dilatation}

FMD is a well-validated and widely used noninvasive method for assessment of endothelium dysfunction in conduit arteries, such as the brachial, radial, and femoral artery [26, 27]. It is based on ultrasound imaging of the artery at rest and after reactive hyperemia, produced either after arterial occlusion by a suprasystolic cuff inflation (endothelium-dependent vasodilation) or after administration of an exogenous NO donor such as a sublingual nitroglycerin dose (endothelium-independent vasodilation) $[28,29]$. Arterial diameter is recorded at 
Table 2. Cohort studies using functional techniques to evaluate the associations of endothelial dysfunction with hard outcomes

\begin{tabular}{|c|c|c|c|c|c|c|c|}
\hline Study & Method & $N$ & Participants & $\begin{array}{l}\text { Follow-up } \\
\text { duration }\end{array}$ & Study variables & Outcome & Results \\
\hline $\begin{array}{l}\text { London } \\
\text { et al. [22] }\end{array}$ & VOP & 78 & $\begin{array}{l}78 \text { hemo- } \\
\text { dialysis }\end{array}$ & $\begin{array}{l}60 \pm 27 \\
\text { months }\end{array}$ & $\begin{array}{l}\text { VOP (FBF, } \\
\text { FDR\%) } \\
\text { Office BP } \\
\text { cIMT } \\
\text { PWV } \\
\text { LVMI }\end{array}$ & $\begin{array}{l}\text { All-cause } \\
\text { mortality }\end{array}$ & $\begin{array}{l}\downarrow \text { FDR was independently associated with all-cause } \\
\text { mortality (RR } 0.69 \text { for every } 10 \% \text { increase; } 95 \% \text { CI: } \\
0.56-0.85 \text { ) } \\
\uparrow \text { PWV was independently associated with all-cause } \\
\text { mortality (RR } 1.16 \text { for } 1 \mathrm{~m} / \mathrm{s} \text { increase; } 95 \% \text { CI: } 1.04- \\
1.29 \text { ) }\end{array}$ \\
\hline $\begin{array}{l}\text { Kruger } \\
\text { et al. [28] }\end{array}$ & LDF & 70 & $\begin{array}{l}70 \text { hemo- } \\
\text { dialysis }\end{array}$ & 2 years & $\begin{array}{l}\text { LDF } \\
\text { measurements } \\
\text { (LDPM during } \\
\text { PORH and TH) } \\
\text { CRP } \\
\text { Framingham and } \\
\text { Cardiorisk scores }\end{array}$ & $\begin{array}{l}\text { CV mortality } \\
\text { and surrogate } \\
\text { endpoints } \\
\text { (CAD, MI, } \\
\text { cerebrovascular } \\
\text { accidents, } \\
\text { peripheral } \\
\text { arterial disease, } \\
\text { and CHF) }\end{array}$ & $\begin{array}{l}\text { Framingham and Cardiorisk scores were near } \\
\text { equivalent for low-risk patients, but more divergent } \\
\text { as risk increased } \\
\text { CRP levels and LDF parameters (amplitude of TH } \\
\text { and area under the curve of TH) showed significant } \\
\text { abnormality in high-risk versus low-risk patients } \\
\text { calculated using either Framingham or Cardiorisk } \\
\text { scores } \\
\text { Patients with abnormal LDF parameters showed } \\
\text { increased CV mortality but had similar risk } \\
\text { assessments (Framingham, Cardiorisk, CRP, and } \\
\text { homocysteine) to those with unimpaired LDF } \\
\text { tracings } \\
\text { CV mortality and development of CHF were } \\
\text { associated with the decreased amplitude of the first } \\
\text { thermal peak and the nadir (CV mortality: } p= \\
0.041 / 0.045 \text { and CHF: } p=0.017 / 0.038 \text {, respectively) } \\
\text { Development of CAD was associated with the } \\
\text { postocclusive recruitment of dermal capillaries } \\
(p=0.016)\end{array}$ \\
\hline $\begin{array}{l}\text { Nemcsik } \\
\text { et al. [57] }\end{array}$ & LDF & 105 & $\begin{array}{l}105 \text { hyper- } \\
\text { tensive CKD } \\
\text { patients }\end{array}$ & $\begin{array}{l}66.6 \\
(39.8-80.4) \\
\text { months }\end{array}$ & $\begin{array}{l}\text { LDF } \\
\text { measurements } \\
\text { (coupled with } \\
\text { PORHHA and } \\
\text { acetylcholine and } \\
\text { nitroprusside } \\
\text { administration) } \\
\text { Biomarkers } \\
\text { (Ang-2, ADMA, } \\
\text { and SDMA) }\end{array}$ & $\begin{array}{l}\text { Combined CV } \\
\text { outcome (CV } \\
\text { mortality and } \\
\text { CV events) } \\
\text { Combined total } \\
\text { outcome (all- } \\
\text { cause mortality } \\
\text { and CV events) }\end{array}$ & $\begin{array}{l}\text { Univariate models: lnPORHHA and lnAng- } 2 \\
\text { predicted the combined CV outcome besides age, } \\
\text { diabetes, baseline CV disease, PP, and logCRP } \\
\text { Multivariate analysis: lnPORHHA (HR 0.66, 95\% CI } \\
{[0.49-0.89] \text { per } \ln [\mathrm{mU} \text { s]), age (1.03 [1.01-1.06] per }} \\
\text { year), logCRP }(1.31[1.06-1.64] \text { per ln }[\mathrm{mg} / \mathrm{L}]) \text {, and } \\
\text { diabetes ( } 3.33 \text { [1.70-6.53]) remained significant } \\
\text { predictors of the CV outcome, whereas lnAng-2 did } \\
\text { not enter the model } \\
\text { Neither of the LDF nor biomarkers were an } \\
\text { independent predictor of the combined total outcome }\end{array}$ \\
\hline
\end{tabular}

ADMA, asymmetric dimethylarginine; Ang-2, angiopoietin-2; BP, blood pressure; CAD, coronary artery disease; CHF, congestive heart failure; cIMT, carotid intimamedia thickness; CRP, C-reactive protein; CKD, chronic kidney disease; CV, cardiovascular; FBF, forearm blood flow; FDR, flow debt repayment; eGFR, estimated glomerular filtration rate; FMD, flow-mediated dilatation; HR, hazard ratio; LDF, laser Doppler flowmetry; LVMI, left ventricle mass index; PORH, postocclusive reactive hyperemia; PORHHA; postocclusive reactive hyperemia area; PTH, parathormone; PWV, pulse wave velocity; RR, risk ratio; TH, thermal hyperemia; SDMA, symmetric dimethylarginine; VOP, venous occlusion plethysmography. 
baseline and at end-diastole in order to determine the response of the brachial artery to increase in flow [28]. FMD is expressed as a percentage change from baseline [14]. The changes in brachial artery diameter are caused by shear-stress-induced generation of endothelial-derived vasoactive mediators; this phenomenon is mainly attributed to endothelial release of NO [26]. FMD in the forearm is significantly correlated with the endothelial function in the coronary arteries [30], and it is considered a reliable indicator of $\mathrm{NO}$ bioavailability in various populations, including CKD and essential hypertensive patients [2]. Moreover, reactive hyperemia flow and induced shear stress (the stimuli for FMD) are considered to be a valid measure of peripheral microvascular function [2]. Indeed, hyperemia-induced shear stress and velocity changes have shown stronger correlations with cardiovascular risk factors than FMD [2]. Even though this method is commonly applied in clinical research and its principle seems to be simple, its application is challenging; it has high inter- and intraobserver variability that can affect the method reproducibility, so it requires good standardization, adherence to strict protocols, and welltrained and experienced operators (Table 1) [2, 14, 27]. Moreover, appropriate subject preparation (physical and environmental factors and medication) is vital in order to control any confounders that may affect vascular reactivity $[27,29]$.

Many observational studies used FMD for assessment of microvascular function in individuals with CKD. FMD levels were found to be lower in CKD patients compared to healthy individuals, and they were significantly decreased from stage 1 to stage $5 \mathrm{CKD}$, while they increase after renal transplantation [31-34]; BP levels were the major determinant of FMD in patients with CKD and no other comorbidities [35], while in other works, fibroblast growth factor-23 (FGF23), 25-OH vitamin D, and serum phosphate were independently associated with FMD [36].

In a seminal study, Verbeke et al. [37] studied variations of vasomotor tone in response to hand warming by comparing shear-stress-mediated changes in brachial artery diameter obtained by FMD between 35 ESKD patients with and without known cardiovascular disease and 22 healthy controls; a negative association between changes in FMD and presence of ESKD or cardiovascular disease was noted. In another study, FMD was reversely correlated with CRP and left ventricle mass index (LVMI); the association between LVMI and FMD was independent of other traditional risk factors (i.e., age, diabetes, and smoking) [38]. Similar observations were also evi-

Microvascular Function Assessment in CKD dent in a cross-sectional study in 149 individuals with ESKD [39]. Other studies have indicated that FMD is associated with hemoglobin, IL-10, IL-33, suppression of tumorigenicity 2 (ST2), and serum sclerostin and visfatin levels [40-43]. In a cohort of 304 nondialyzed CKD patients, decreased FMD was strongly associated with cardiovascular events and mortality ( $\mathrm{HR}=0.52$ with $95 \% \mathrm{CI}$ [0.37-0.73]) (Table 2) [33].

Furthermore, several clinical trials have applied FMD in order to test the effects of different interventions on microvascular function in CKD. In an 8-week randomized, double-blind, placebo-controlled trial in $70 \mathrm{CKD}$ patients, rosiglitazone reduced significantly insulin resistance and endothelial dysfunction markers but not FMD and arterial stiffness parameters [44]. In CKD stage 3-5, atorvastatin and gemfibrozil were not associated with improvement in FMD and endothelial-independent vasodilatation compared to placebo [45]. In addition, in a double-blind randomized trial in 60 patients with advanced diabetic kidney disease, paricalcitol did not affect FMD and other inflammation biomarkers compared to placebo [46]. These findings are expanded in a meta-analysis of studies examining the effect of vitamin D supplementation in patients with $\mathrm{CKD}$, where no significant differences in levels of FMD between the active and control groups were observed [47]. Finally, in a prospective study in 42 ESKD patients, forearm FMD was significantly increased in patients undergoing high-efficiency online hemodiafiltration compared to high-flux hemodialysis [48].

\section{Laser Doppler Flowmetry}

Laser Doppler flowmetry (LDF) is a reliable indicator of skin microvasculature function; it is based on diffusion and refraction of laser beam light [49]. The main principle relies on the Doppler effect; by changing the direction of the laser beam, the alterations in light wavelength reflect the number and velocity of erythrocytes inside the microvessels [11]. Many techniques can be associated with LDF involving postocclusive reactive hyperemia, thermal hyperemia, iontophoresis, and microdialysis. Local thermal hyperemia leads to a temperature-dependent rise in skin blood flow and achieves a maximal vasodilatation which corresponds to the maximal vasodilator vessel capacity [49]. Iontophoresis is based on the principle that electrically charged drugs in solution will migrate across the skin under the influence of a direct low-intensity electric current [50]. When coupled with LDF, iontophoresis enables the detection of changes in skin blood flow in response to vasoactive drug administration (i.e., acetylcholine and sodium nitroprusside) [11]. Acetylcholine and 
sodium nitroprusside are used to assess endothelium-dependent and -independent vasodilation, respectively [11]. Microdialysis allows pharmacological compounds to be delivered directly to an area of the skin vessels without exerting systemic effects, even if these compounds are nonpolar and have higher molecular weight that would be difficult to deliver by iontophoresis [51]. Coupling this technique with LDF allows for real-time measurement of skin blood flow changes during localized infusion of pharmacological agents [51]. Although simple and easy to perform, LDF is considered to be poorly reproducible (Table 1) [52].

As of this writing, several studies have used LDF alone or combined with one of the 4 aforementioned methods to evaluate microvascular function in individuals with CKD. In a cross-sectional study including hypertensive CKD patients and hypertensive controls without CKD, CKD patients had lower response to postocclusive reactive hyperemia. LDF response to both postocclusive reactive hyperemia and thermal hyperemia was strongly associated with the presence of albuminuria and CKD, independent of diabetes and BP levels [53]. Another study showed that young CKD patients had impaired endothelium-dependent and endothelium-independent vasodilation (evaluated by iontophoresis) compared to similar age healthy controls but similar microvascular function to elderly CKD patients [54]. Mitochondria-derived reactive oxygen species suggested to play a major role in this microvascular dysfunction [55]. Farkas et al. [56] observed that hemodialysis patients with hypertension have impaired endothelium-dependent and endothelium-independent vasodilation and higher levels of endothelial dysfunction markers compared to essential hypertensives and healthy individuals.

In a cohort of 105 nondialysis CKD patients, postocclusive reactive hyperemia area changes evaluated by LDF independently predicted cardiovascular events and mortality (Table 2) [57]. Similar associations with cardiovascular disease were also observed in other studies in ESKD patients $[58,59]$. Finally, in a recent clinical trial including 36 nondialysis CKD patients, 12 weeks of aerobic exercise improved microvascular function and maintained conduit artery function measured by LDF coupled with microdialysis [60].

\section{Arterial Glycocalyx Functional Assessment}

Glycocalyx is a complex of glycosaminoglycans and proteoglycans covering the surface of endothelial cells and is considered to protect the vasculature wall against pathogenic insults in cardiovascular disease [52]. It plays a significant role in transferring shear stress into sheardependent endothelial responses, leading to NO release [14]. Both invasive and noninvasive techniques can be used to assess glycocalyx function [14]. Historically, one of the first methods described to estimate systemic glycocalyx volume was the tracer dilution method [61]. In this technique, systemic glycocalyx volume is measured using the glycocalyx permeable tracer (i.e., Dextran 40) versus a glycocalyx impermeable tracer (i.e., fluorescein-labeled erythrocytes) $[14,61]$. Despite the fact that this technique can directly estimate the whole-body glycocalyx volume, its application is limited due to its invasiveness and timeconsuming preparations (Table 1) [14]. New techniques have also emerged in the field of optics, using orthogonal polarization spectral (OPS) and sidestream dark field (SDF) imaging at the superficial microvasculature [14]. These procedures are simple, noninvasive, painless, and rapid, and they can be executed at bedside (Table 1) [62, 63]. These methods use the erythrocyte-endothelium gap of the capillaries in the image to quantify glycocalyx thickness [64]. Perfused boundary region (PBR) (calculated as the distance between red blood cell column and red blood cell impermeable glycocalyx) is an SDF-measured parameter that is inversely related to glycocalyx thickness; large PBR values are an indirect measure of an impaired glycocalyx [65].

Studies using arterial glycocalyx to assess endothelial dysfunction in CKD are scarce. In a rat model with proteinuric CKD, loss of endothelial glycocalyx was linked to albuminuria and vascular dysfunction [66]. In a human study, Vlahu et al. [67] used SDF to detect differences in glycocalyx dimension between 40 hemodialysis patients and 21 healthy controls and showed that PBR was increased in hemodialysis patients, suggesting an impaired glycocalyx barrier.

\section{Laser Speckle Contrast Imaging}

LSCI is a novel, fast, noninvasive technique that provides continuous measurement of skin blood flow. It is based on the principle of tracking the "speckle pattern" (i.e., the backscattered light from a tissue that is illuminated with laser light forms a random interference pattern at the detector) (Fig. 1). When coupled with reactivity tests such as postocclusive reactive hyperemia and local thermal hyperemia, LSCI showed improved reproducibility compared to the aforementioned method of LDF [68]. So far, it has been used to evaluate different circulatory beds $[69,70]$ and for assessment of endothelium-dependent vasodilator responses in patients with type-1 DM and coronary artery disease (CAD) $[71,72]$. 
1

Fig. 1. Assessment of skin endothelial function with LSCI depicting the position of the forearm under the laser light beam and the skin sites used for microvascular response recording. LSCI, laser speckle contrast imaging.

Fig. 2. Assessment of skin endothelial function with nailfold video capillaroscopy: capillaries are depicted in the middle of the nailfold, $\sim 4.5 \mathrm{~mm}$ near the terminal capillary line on the skin of the distal phalanx of the dorsal fourth finger of the right upper hand.

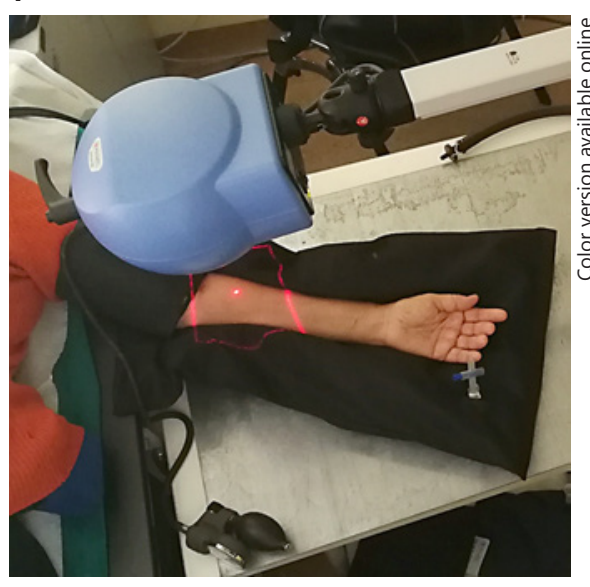

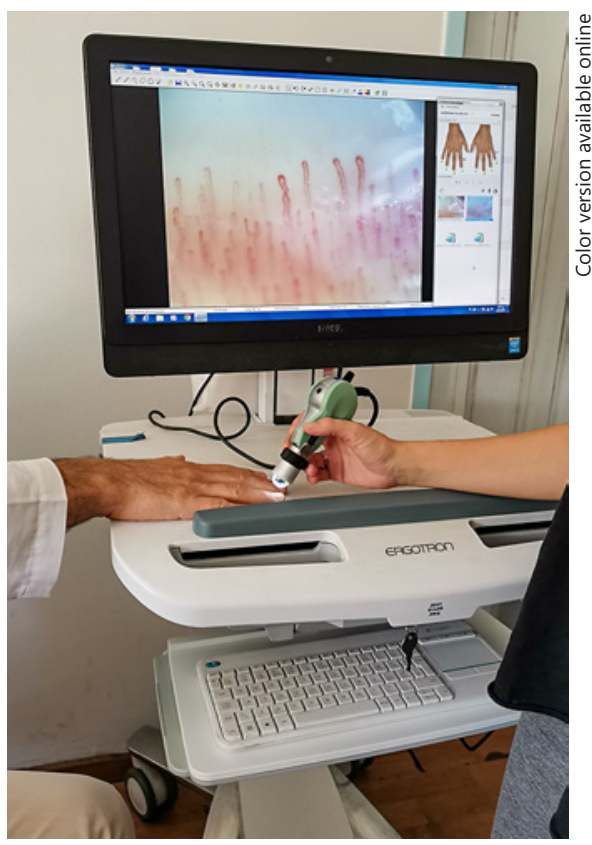

To date, there is only one study which used LSCI to evaluate microvascular function in patients with CKD. In this study, Alexandrou et al. [73] included 38 hemodialysis patients, 38 peritoneal dialysis patients, and 38 controls matched in a 1:1:1 ratio and found that patients under hemodialysis and peritoneal dialysis exhibit similar time to peak response, increase (\%) from baseline to peak perfusion, peak cutaneous vascular conductance, cutaneous vascular conductance increase (\%) at peak, and postocclusive reactive hyperemia response, all of which were significantly impaired compared to controls, findings suggesting that skin capillary recruitment and endothelial function in response to hyperemia are severely disturbed in ESKD patients.

\section{Nailfold Capillaroscopy}

Nailfold capillaroscopy is an easily applicable, noninvasive technique used to evaluate microcirculation and endothelial function [74-76]. It provides information for multiple microcirculatory parameters, including capillary morphology and density and flow velocity [74, 76]. The reduction in the density of capillaries in any given visual field is called capillary rarefaction and is categorized into 2 types: structural (i.e., decrease in overall number of capillaries) and functional (i.e., reduction in the number of perfused capillaries) rarefaction (Fig. 2) [74, 76]. Video capillaroscopy offers the advantage of evaluation of capillary density in 3 phases: baseline, during hyperemia after arterial occlusion (postocclusive reactive hyperemia), and after venous congestion (Table 1) [76]. Capillary density during venous congestion is considered the best method to objectively assess the anatomic capillary number, as it can expose nonperfused capillaries that are missed with simple capillaroscopy. Furthermore, the postocclusive hyperemic phase detects the functional recruitment of initially nonperfused capillaries (measure of structural and functional integrity) [77].

To date, few studies have used nailfold video capillaroscopy to explore the subject of capillary rarefaction in CKD. Thang et al. [78] evaluated 35 CKD stage 5 (20 hemodialysis and 15 peritoneal dialysis) patients, 19 predialysis patients, and 19 controls and observed that baseline capillary density was impaired in both CKD groups. Capillary recruitment during postocclusive reactive hyperemia and venous occlusion was also lower in both CKD groups compared to controls; these alterations were independently associated with increased serum phosphorus and bicarbonate [78]. Furthermore, Edwards-Richards et al. [79] studied 19 pediatric hemodialysis patients and 20 controls and showed that capillary rarefaction was strongly associated with biomarkers of altered mineral metabolism. Finally, in a very recent study of our group in 96 CKD stage 2-4 patients, we have demonstrated that both structural and functional capillary density progressively decreased with advancing CKD stages (Fig. 3); reduced eGFR, diabetes, and increased PTH levels are independently and inversely associated with functional capacity density [76]. 
Fig. 3. Capillary density during baseline, after postocclusive reactive hyperemia, and during venous congestion among different stages of CKD (reprinted with permission from Schoina et al. [76], Hypertens Res. 2020).

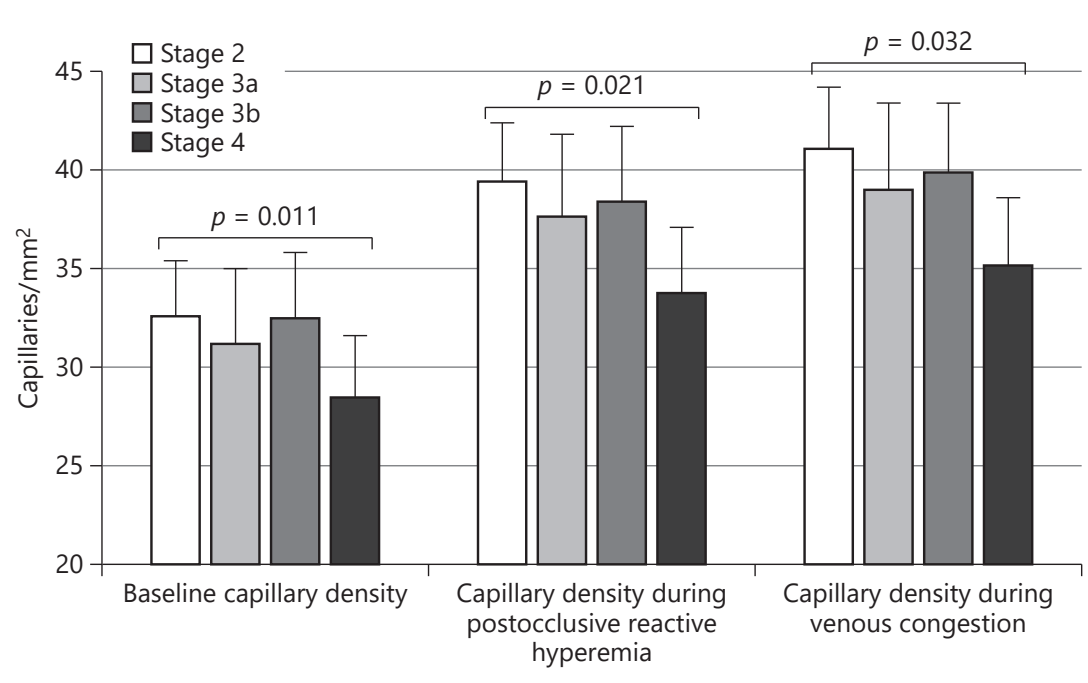

In a 3-month randomized, double-blind, placebo-controlled trial in 36 subjects with moderate CKD, paricalcitol treatment was associated with a trend toward improvement in toe video capillaroscopy parameters [80]. In another nonrandomized, pilot study including 15 CKD stage 3-4 patients and 15 controls, short-term administration of recombinant human growth hormone resulted in increase of capillary blood flow at baseline and during reactive hyperemia in both groups [81].

\section{Near-Infrared Spectroscopy}

NIRS is a relevant new, costless, noninvasive method that assesses local tissue oxygenation and can provide valuable information about local oxygen consumption and blood flow [51]. It is based on the "modified BeerLamberts Law" [82]. A simple NIRS device consists of a light source (that produces light in the near-infrared range into the examined tissue) and a detector; hemoglobin and myoglobin are oxygen carriers in blood and skeletal muscles, respectively, and their absorbance of nearinfrared light differs depending on their oxygenation state [82]. NIRS allows to assess microvascular reactivity and skeletal muscle oxygenation at rest and during exercise, via continuous monitoring of functional changes in oxygenated hemoglobin dissociation [83]. Using postocclusion reactive hyperemia, NIRS technology provides information on skeletal muscle's oxidative capacity, microvascular function, and muscle oxygenation at rest and during exercise [83]. With regard to cerebral oxygenation, NIRS noninvasively monitors alterations and assesses relative changes from baseline for oxygenated, de- oxygenated, and total hemoglobin [84]. Due to its ability to assess microvascular function, NIRS has been applied in various populations with impaired microvascular function, including patients with essential hypertension, DM, CAD, and ESKD [83, 85-87].

As shown in Table 3, only one small study (24 cases and 6 controls) up to date has evaluated muscle oxygenation via NIRS in nondialysis CKD patients. In this study, Wilkinson et al. [88] described NIRS-derived skeletal muscle $\mathrm{O}_{2}$ saturation changes during and following exercise and found that CKD patients have dysfunctional kinetics that may indicate reduced mitochondria capacity to perform oxidative phosphorylation. Moreover, there are few studies examining muscle oxygenation via NIRS in ESKD individuals. In one of them, the presence of dialysis access resulted in decreased muscle oxygenation and strength even in the absence of clinically overt hand ischemia [89]. In another study, regional saturation of oxygen $\left(\mathrm{rSO}_{2}\right)$ of muscles was significantly lower in hemodialysis patients compared to healthy controls, and this was associated with serum inorganic phosphate and albumin levels [90]. In an EXerCise-Introduction-To-Enhance-performance-in-dialysis (EXCITE) substudy, resting muscle oxygen consumption was significantly lower in patients with ESKD compared to healthy controls, but it was improved after a 6-month exercise program [87]. NIRS has been also utilized to examine the alterations in microvascular function and muscle oxygenation during the hemodialysis session; the findings indicate that hemodialysis brings about major changes in skeletal muscle oxygenation, blood flow, microvascular compliance, and 
Table 3. Studies using NIRS for evaluation of muscle oxygenation and microvascular function in CKD [144-146]

\begin{tabular}{|c|c|c|c|c|c|}
\hline Study & Study type & $N$ & Participants & Study variables & Results \\
\hline $\begin{array}{l}\text { Vaux } \\
\text { et al. [144] }\end{array}$ & $\begin{array}{l}\text { Phase-2, } \\
\text { double-blind } \\
\text { RCT }\end{array}$ & 26 & $\begin{array}{l}26 \mathrm{HD} \text { (13 in the } \\
\text { carnitine group and } \\
13 \text { in the control } \\
\text { group) }\end{array}$ & $\begin{array}{l}T_{1 / 2} \text { of muscle reoxygenation } \\
\text { measured via NIRS and other } \\
\text { parameters measured via }{ }^{31} \mathrm{P} \\
\text { magnetic resonance } \\
\text { spectroscopy and }{ }^{1} \mathrm{H} \text { magnetic } \\
\text { resonance imaging at baseline } \\
\text { and at } 16 \text { weeks }\end{array}$ & $\begin{array}{l}\text { L-Carnitine had no statistically significant effect on any of } \\
\text { the parameters measured }\end{array}$ \\
\hline $\begin{array}{l}\text { De Blasi } \\
\text { et al. [91] }\end{array}$ & Observational & 20 & $\begin{array}{l}20 \mathrm{HD}(10 \mathrm{DM} \text { and } \\
10 \text { non-DM) and } 22 \\
\text { healthy controls for } \\
\text { baseline comparisons }\end{array}$ & $\begin{array}{l}\text { Once hourly during dialysis } \\
{[\mathrm{HbT}],\left[\mathrm{HbO}_{2}\right] \text {, and }[\mathrm{HHb}]} \\
\mathrm{mBF} \text {, microvascular } \\
\text { compliance, and } \mathrm{mVO}_{2} \text { after } \\
\text { venous occlusion } \\
\mathrm{StO}_{2} \text { and } \mathrm{CtO}_{2} \text {, microvascular } \\
\text { bed volume }\end{array}$ & $\begin{array}{l}\uparrow[\mathrm{HbT}] \text { and }[\mathrm{HHb}] \text { during dialysis in patients without and } \\
\text { with diabetes } \\
\text { In diabetic: } \uparrow\left[\mathrm{HbO}_{2}\right] \text { and } \mathrm{CtO}_{2} \text { during dialysis but left } \\
\mathrm{mVO}_{2} \text { unchanged } \\
\mathrm{StO}_{2} \text { significantly positively correlated with } \mathrm{HbO}_{2} \text { and } \\
\text { negatively with } \mathrm{mVO}_{2} \\
\text { Dialysis increased } \mathrm{mBF} \text { only in diabetic patients } \\
\text { Microvascular compliance decreased rapidly and } \\
\text { significantly during the first hour of dialysis in both groups }\end{array}$ \\
\hline $\begin{array}{l}\text { Manfredini } \\
\text { et al. [87] }\end{array}$ & $\begin{array}{l}\text { Parallel-group } \\
\text { RCT }\end{array}$ & 59 & $\begin{array}{l}59 \mathrm{HD} \text { ( } 31 \text { in the } \\
\text { exercise group and } \\
28 \text { in control) (in } \\
\text { addition, normative } \\
\text { data for } \mathrm{rmVO}_{2} \text { were } \\
\text { obtained from a } \\
\text { group of } 19 \text { healthy } \\
\text { subjects) }\end{array}$ & $\begin{array}{l}\mathrm{rmVO}_{2} \text { at baseline and after } \\
6 \text { months }\end{array}$ & $\begin{array}{l}\text { Baseline } \\
\mathrm{rmVO}_{2} \text { was higher }(p<0.001) \text { in ESKD }(0.083 \pm 0.034 \\
\mathrm{mL} / 100 \mathrm{~g} / \mathrm{min}) \text { than in healthy subjects }(0.041 \pm 0.020 \\
\mathrm{mL} / 100 \mathrm{~g} / \mathrm{min}) \\
\mathrm{rmVO}_{2} \text { correlated with resting } \mathrm{HR}(r=0.34, p=0.009) \\
\text { Study end } \\
\text { Exercise group: } \downarrow \mathrm{rmVO}_{2}[0.064 \pm 0.024 \mathrm{~mL} / 100 \mathrm{~g} / \mathrm{min} \\
(-23 \%, p<0.001)] \\
\text { Control group: } \mathrm{rmVO} \mathrm{F}_{2} \text { no change }(0.082 \pm 0.032 \mathrm{vs} \text {. } \\
0.082 \pm 0.031 \mathrm{~mL} / 100 \mathrm{~g} / \mathrm{min})\end{array}$ \\
\hline $\begin{array}{l}\text { Pipili } \\
\text { et al. [145] }\end{array}$ & Observational & 28 & $\begin{array}{l}11 \mathrm{HD}, 9 \\
\text { hemodiafiltration, } \\
8 \text { healthy controls }\end{array}$ & $\begin{array}{l}\text { Thenar } \mathrm{StO}_{2} \text { at baseline and } \\
\text { after venous occlusion test (rate } \\
\text { of } \mathrm{Hb} \text { desaturation [oxygen } \\
\text { consumption rate], } \mathrm{StO}_{2} \text { growth } \\
\text { curve rate [endothelial } \\
\text { function], hyperemia phase } \\
\text { [vascular reactivity] before and } \\
\text { after the dialysis session }\end{array}$ & $\begin{array}{l}\text { Predialysis endothelial function }(9.1 \pm 5.6 \text { vs. } 15.7 \pm 6.3 \text {, } \\
p=0.003) \text { and vascular reactivity were lower in ESKD } \\
\text { compared to healthy } \\
H D \\
\uparrow \text { oxygen consumption rate after } \mathrm{HD}(24.5 \pm 7.540 \pm 17.7 \text {, } \\
p=0.03) \text { correlated with } \mathrm{Kt} / \mathrm{V}(r=0.74, p=0.03) . \\
\text { Predialysis } \mathrm{StO}_{2} \text { correlated with PTH }(r=0.90, p<0.001) \\
\text { Hemodiafiltration: } \text { no differences }\end{array}$ \\
\hline $\begin{array}{l}\text { Miyazawa } \\
\text { et al. [90] }\end{array}$ & Observational & 81 & $\begin{array}{l}67 \mathrm{HD} \text { and } 15 \\
\text { healthy controls }\end{array}$ & $\begin{array}{l}\mathrm{rSO}_{2} \text { of the gastrocnemius } \\
\text { before dialysis }\end{array}$ & $\begin{array}{l}\mathrm{rSO}_{2} \text { values were lower in } \mathrm{HD} \text { compared to healthy } \\
(50.0 \pm 1.7 \text { vs. } 76.8 \pm 2.5 \%, p<0.001) \\
\mathrm{rSO}_{2} \text { was independently associated with serum inorganic } \\
\text { phosphate (standardized coefficient: } 0.27 \text { ) and serum } \\
\text { albumin concentrations (standardized coefficient: } 0.24) \\
\text { No differences in } \mathrm{rSO}_{2} \text { between diabetic and nondiabetic } \\
\text { HD patients }\end{array}$ \\
\hline $\begin{array}{l}\text { Malik } \\
\text { et al. [97] }\end{array}$ & Observational & 44 & $\begin{array}{l}27 \mathrm{HD} \text { and } 17 \\
\text { age-matched } \\
\text { healthy controls }\end{array}$ & $\begin{array}{l}\mathrm{rSO}_{2} \text { was measured at the brain } \\
\text { frontal lobe and at the hand } \\
\text { with dialysis access at rest and } \\
\text { during HD }\end{array}$ & $\begin{array}{l}\text { Dialysis patients had } \downarrow \text { rest brain } \mathrm{rSO}_{2}(51.5 \pm 10.9 \text { vs. } \\
68 \pm 7 \%, p<0.001) \text { and hand } \mathrm{rSO}_{2}(55 \pm 16 \text { vs. } 66 \pm 8 \% \text {, } \\
p=0.03) \\
\text { Both values } \downarrow \downarrow \text { during the first } 35 \text { min of } \mathrm{HD} \text { (brain: } \mathrm{rSO}_{2} \\
\text { to } 47 \pm 8 \%, p<0.001 \text {, and hand to } 45 \pm 14 \%, p<0.001) \\
\mathrm{Brain}_{\mathrm{rSO}} \text { decrease was related to the UF rate and hand } \\
\mathrm{rSO}_{2} \text { decrease to the finger pressure and to } \mathrm{Hb}\end{array}$ \\
\hline $\begin{array}{l}\text { Kmentova } \\
\text { et al. [89] }\end{array}$ & Observational & 79 & $\begin{array}{l}52 \mathrm{HD} \text { and } 27 \\
\text { healthy controls }\end{array}$ & $\begin{array}{l}\mathrm{rSO}_{2} \text {, handgrip strength, and } \\
\text { finger systolic BP performed in } \\
\text { both the hands before } \mathrm{HD} \\
\text { session }\end{array}$ & $\begin{array}{l}\text { Hands with dialysis access had } \downarrow \text { values of handgrip } \\
\text { strength, systolic finger pressure, and of thenar } \mathrm{rSO}_{2} \\
(45.8 \pm 12.9 \text { vs. } 42.5 \pm 13.3 \%, p=0.002) \\
\text { On access hand: handgrip strength was related to the thenar } \\
\text { oxygenation }(r=0.36 ; p=0.014) \text { and to the finger systolic } \\
\text { pressure }(r=0.38 ; p=0.007) \\
\text { On the nonaccess hand: handgrip strength was inversely } \\
\text { related to age }(r=-0.41, p=0.003) \text {, dialysis vintage } \\
(r=-0.32, p=0.02) \text {, and } \operatorname{RDW}(r=-0.37, p=0.01)\end{array}$ \\
\hline
\end{tabular}


Table 3 (continued)

\begin{tabular}{|c|c|c|c|c|c|}
\hline Study & Study type & $N$ & Participants & Study variables & Results \\
\hline $\begin{array}{l}\text { Ookawara } \\
\text { et al. [146] }\end{array}$ & Observational & 53 & $53 \mathrm{HD}$ & $\begin{array}{l}\mathrm{rSO}_{2} \text { and } \mathrm{HbT} \text { signal strength } \\
\text { in the brain, liver, and lower- } \\
\text { limb muscle during HD }\end{array}$ & $\begin{array}{l}\downarrow \text { brain versus liver } \mathrm{rSO}_{2} \text { from } \mathrm{HD} \text { start to the end (HD } \\
\text { start } 46.5 \pm 1.3 \text { vs. } 52.4 \pm 1.7 \%, p=0.031 \text { ) } \\
\uparrow \text { liver and muscle } \mathrm{HbT} \text { signal strength ratio compared to } \\
\text { brain during } \mathrm{HD}\end{array}$ \\
\hline $\begin{array}{l}\text { Wilkinson } \\
\text { et al. [88] }\end{array}$ & Observational & 30 & $\begin{array}{l}24 \text { nondialysis CKD } \\
\text { patients and } 6 \text { healthy } \\
\text { controls }\end{array}$ & $\begin{array}{l}\text { Muscle } \mathrm{SMO}_{2} \% \text { before, during, } \\
\text { and after (recovery) ISWT }\end{array}$ & $\begin{array}{l}\downarrow \mathrm{SMO}_{2} \% \text { during exercise, followed by rapid } \uparrow \text { upon } \\
\text { recovery } \\
\text { CKD patients with higher exercise capacity (ISWT } \\
\text { distance: } 727.1 \pm 38.1 \mathrm{~m}) \text { took } 45 \% \text { longer to reach their } \\
\text { minimum } \mathrm{SMO}_{2} \%(p=0.038) \text { and recovered } 79 \% \text { faster } \\
\text { ( } p=0.046) \text { compared to patients with lower exercise } \\
\text { capacity (ISWT: } 727.1 \pm 38.1 \mathrm{~m}) \\
\text { CKD patients took significantly } 56 \% \text { longer to recover } \\
(p=0.014) \text { compared to controls }\end{array}$ \\
\hline
\end{tabular}

NIRS, near-infrared spectroscopy; DM, diabetes mellitus; $\mathrm{BP}$, blood pressure; $\mathrm{CKD}$, chronic kidney disease; $\mathrm{CtO}_{2}$, oxygen tissue content; ESKD, endstage kidney disease; $\mathrm{Hb}$, hemoglobin; $\mathrm{HD}$, hemodialysis; [HHb], deoxygenated $\mathrm{Hb}$ concentration; $\left[\mathrm{HbO}_{2}\right]$, oxygenated $\mathrm{Hb}$ concentration; [HbT], total $\mathrm{Hb}$ concentration; HR, heart rate; ISWT, incremental shuttle walk test; $\mathrm{mBF}$, muscular blood flow; $\mathrm{mVO}_{2}$, muscle oxygen consumption; PTH, parathormone; RCT, randomized clinical trial; RDW, red cell distribution width; $\mathrm{rmVO}_{2}$, resting muscle oxygen consumption; $\mathrm{rSO}_{2}$, regional saturation of $\mathrm{O}_{2}$; $\mathrm{SMO}_{2}$, skeletal muscle $\mathrm{O}_{2} ; \mathrm{StO}_{2}$, tissue oxygen saturation; UF, ultrafiltration.

tissue metabolic rate, and that all except from microvascular compliance were more impaired in patients with DM compared to patients without DM [91].

Studies applying cerebral NIRS in CKD patients are scarce. In early studies, patients undergoing hemodialysis show significantly lower cerebral $\mathrm{rSO}_{2}$ levels compared to healthy individuals; cerebral oxygenation was more impaired in diabetic than nondiabetic hemodialysis patients $[92,93]$. The presence of severe anemia deteriorated cerebral oxygenation in this population $[94,95]$. In an observational study in 23 hemodialysis and 9 peritoneal dialysis patients scheduled to undergo surgery, peritoneal dialysis patients had significantly higher $\mathrm{rSO}_{2}$ levels compared to hemodialysis [96]. In a retrospective study including 49 patients ( 9 hemodialysis and 40 nonhemodialysis) that underwent coronary artery bypass graft surgery, hemodialysis patients had lower $\mathrm{rSO}_{2}$ levels, even after adjusting for age, hemoglobin, and LV ejection fraction [97]. A cross-sectional study including 104 hemodialysis patients indicated that cerebral $\mathrm{rSO}_{2}$ significantly decreased as aortic-arch calcification progressed and was independently associated with serum phosphate and history of smoking [98]. Finally, studies evaluating cerebral oxygenation during dialysis session have shown that cerebral oxygenation deteriorates after the beginning of hemodialysis [93, 99]; cerebral ischemia cannot be predicted from BP alterations during dialysis, and this leads to high risk of stroke and cognitive dysfunction development $[100,101]$.

\section{Assessment of Endothelial Dysfunction in CKD: Biochemical Markers}

Over the years, several circulatory substances have been used as markers of endothelial function in human studies. The most important of them are summarized in Table 4. A detailed description of all these biomarkers is beyond the scope of this review. In the following lines, we concisely discuss the most important biomarkers used to assess endothelial dysfunction in CKD patients.

\section{Asymmetric Dimethylarginine}

Asymmetric dimethylarginine (ADMA) is an endogenous inhibitor of NO synthase and a strong marker of atherosclerosis [102]. Several studies demonstrated that ADMA is also strongly and independently associated with noninvasive measurements of endothelial dysfunction [103]. Patients with CKD have significantly higher ADMA levels than healthy individuals [103]. Furthermore, among patients with CKD, ADMA is inversely related to GFR [104]. For example, in a previous study of our group, ADMA levels were higher in patients with autosomal-dominant polycystic kidney disease (ADPKD) and eGFR $<70 \mathrm{~mL} / \mathrm{min} / 1.73 \mathrm{~m}^{2}$, compared to age- and sex-matched patients with ADPKD and eGFR $>70 \mathrm{~mL} /$ $\min / 1.73 \mathrm{~m}^{2}$, and higher in the 2 aforementioned groups compared to age- and sex-matched controls with preserved eGFR. A negative association between ADMA levels and eGFR $(r=-0.460, p<0.001)$ was observed [105]. 
Table 4. Summary of the most commonly used endothelial dysfunction circulating biomarkers in human studies

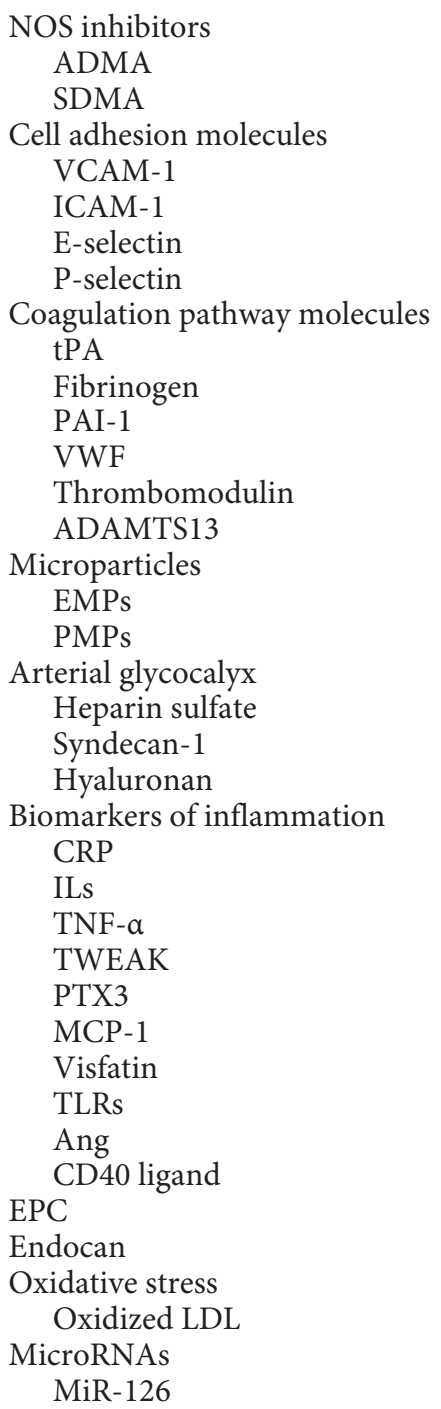

Endocan

Oxidative stress

Oxidized LDL

MicroRNAs

MiR-126

NOS, nitric oxide synthase; ADMA, asymmetric dimethylarginine; SDMA, symmetric dimethylarginine; VCAM-1, vascular cell adhesion molecule 1; ICAM-1, intracellular adhesion molecule 1; tPA, tissue plasminogen activator; PAI-1, plasminogen activator inhibitor 1; VWF, von Willebrand factor; EMPs, endothelial microparticles; PMPs, platelet microparticles; CRP, C-reactive protein; ILs, interleukins; TNF- $\alpha$, tumor necrosis factor-alpha; TWEAK, TNF-like weak inducer of apoptosis; PTX3, pentraxin 3; MCP-1, monocyte chemoattractant protein-1; TLRs, Toll-like receptors; Ang, angiopoietin; EPC, endothelial progenitor cell.

In patients with CKD, ADMA levels have been associated with carotid intima-media thickness (cIMT) and coronary calcification [106-108] as well as with proteinuria and LVH [109-111]. Therefore, it was no surprise that ADMA was found to be an independent predictor of

Microvascular Function Assessment in CKD progression to dialysis, cardiovascular outcomes, and death in these individuals [104, 112-116]; a detailed description of these studies can be found in Table 5. Of note, both ADMA levels and endothelial dysfunction improve after renal transplantation [117]; in renal transplant, recipient ADMA levels are associated with graft function deterioration and mortality [118].

\section{Cell Adhesion and Coagulation Pathway Molecules}

Vascular adhesion molecule 1 (VCAM-1), intracellular adhesion molecule 1 (ICAM-1), and endothelial selectin (E-selectin) are considered endothelial-specific biomarkers [119]. Compounds involved in the coagulation cascade (i.e., fibrinogen and von Willebrand factor [VWF]) are considered related but not specific markers of endothelial dysfunction [120]. In the general population, eGFR is inversely associated with circulating adhesion molecules [121]. In nondialysis patients with CKD, creatinine clearance was inversely correlated with VCAM1 and VWF levels [122]. Levels of VCAM-1 and ICAM-1 increase in parallel with the progression to CKD to ESKD [123]. Therefore, patients undergoing hemodialysis have elevated levels of VCAM-1 that are not affected by the dialysis procedure; patients undergoing peritoneal dialysis have also higher levels of VCAM- 1 and ICAM- 1 compared to controls and hemodialysis subjects $[124,125]$.

In nondialysis CKD patients, VCAM-1 levels were associated with higher LVMI [126]. In ESKD patients, Eselectin was reversely related to cardiovascular events, $\mathrm{LVH}$, and total mortality, while a specified E-selectin gene polymorphism was associated with carotid atherosclerosis [127-129]. In a previous work, E-selectin and ICAM-1 were also correlated with salt and water retention in ESKD [130].

\section{Endothelial Microparticles}

Endothelial microparticles (EMPs) are vesicles shed from plasma membranes following endothelial cell activation or apoptosis; elevated EMP levels are considered the most specific marker of endothelial dysfunction [14]. Endothelial NOS uncoupling and low shear stress are linked with EMP levels [14]. In a seminal study in 34 ESKD patients, Boulanger et al. [131] showed that EMPs were elevated through low shear stress, and this was also linked to the presence of anemia. Activation of the alternative complement pathway is considered to be a significant mechanism of EMP elevation, as it is strongly related to endothelial dysfunction and CKD indices (eGFR and albumin/creatinine ratio) [132]. Faure et al. [133] examined the association between EMPs and uremic toxins 
Table 5. Cohort studies using ADMA/EMPs to evaluate the associations of endothelial dysfunction with outcomes

\begin{tabular}{|c|c|c|c|c|c|c|}
\hline Study & $\begin{array}{l}\text { Bio- } \\
\text { marker }\end{array}$ & $N$ & Participants & $\begin{array}{l}\text { Follow-up } \\
\text { duration }\end{array}$ & Study variables & Outcome \\
\hline $\begin{array}{l}\text { Zoccali } \\
\text { et al. [112] }\end{array}$ & ADMA & 225 & $\begin{array}{l}225 \\
\text { hemodialysis }\end{array}$ & $\begin{array}{l}33.4 \pm 14.6 \\
\text { months }\end{array}$ & ADMA & $\begin{array}{l}\text { All-cause mortality } \\
\text { CV events (fatal } \\
\text { and nonfatal) }\end{array}$ \\
\hline
\end{tabular}

Results

Univariate analysis: ADMA was related to

fibrinogen, L-arginine, dialysis vintage, serum cholesterol, and albumin

Multivariate analysis: ADMA was correlated with fibrinogen $(p=0.0001)$ and albumin $(p=$ 0.04)

ADMA was the second factor predicting overall mortality (HR 1.26, 95\% Cl [1.111.41]) and CV events (HR 1.17, 95\% CI [1.041.33])

\begin{tabular}{|c|c|c|c|c|c|c|}
\hline $\begin{array}{l}\text { Mallamaci } \\
\text { et al. [116] }\end{array}$ & ADMA & 224 & $\begin{array}{l}224 \\
\text { hemodialysis }\end{array}$ & $\begin{array}{l}42.3(0.2- \\
70.5) \text { months }\end{array}$ & $\begin{array}{l}\text { ADMA } \\
\text { Plasma } \\
\text { norepinephrine }\end{array}$ & $\begin{array}{l}\text { All-cause mortality } \\
\text { CV events (fatal } \\
\text { and nonfatal) }\end{array}$ \\
\hline
\end{tabular}

ADMA was strongly correlated with norepinephrine $(p<0.001)$

Cox models not including ADMA: norepinephrine was a predictor of death (HR $1.06,95 \%$ CI [1.01-1.12]) and CV events (HR $1.08,95 \%$ CI [1.02-1.15])

ADMA introduced into the model: norepinephrine was an insignificant predictor of outcomes, and ADMA was a significant predictor of death (HR 1.22, 95\% CI [1.11$1.35])$ and CV events (HR 1.19, 95\% CI [1.081.32])

\begin{tabular}{llllll}
\hline $\begin{array}{l}\text { Ravani } \\
\text { et al. [104] }\end{array}$ & ADMA & 131 & $\begin{array}{l}\text { 131 CKD stage } \\
2-5 \text { patients }\end{array}$ & $\begin{array}{l}\text { 27 (3.4-36) } \\
\text { months }\end{array}$ & ADMA
\end{tabular}

Progression to ESRD (halving GFR or dialysis start)

All-cause mortality Combined outcome

Univariate analysis: ADMA (HR 1.23, 95\% CI [1.076-1.412]), proteinuria, GFR, hemoglobin, and CaxP product correlated with outcomes. Patients with ADMA levels $<$ median had survival advantage in both event-specific strata $(p<0.001)$ Multivariate analysis: ADMA (HR 1.20, 95\% CI [1.071-1.350]) predicted combined outcome independent of confounders: GFR, proteinuria, hemoglobin, and homocysteine

\begin{tabular}{|c|c|c|c|c|c|}
\hline $\begin{array}{l}\text { Young } \\
\text { et al. [115] }\end{array}$ & ADMA 820 & $\begin{array}{l}820 \text { CKD stage } \\
3-4 \text { patients }\end{array}$ & $\begin{array}{l}9.5(0.25- \\
11.60) \text { years }\end{array}$ & ADMA & $\begin{array}{l}\text { All-cause mortality } \\
\text { CV mortality }\end{array}$ \\
\hline
\end{tabular}

Higher ADMA tertiles were more likely to

have CVD, lower DBP, and lower GFR Univariate analysis: a 1-SD increase in ADMA increased the risk for all-cause (HR 1.18, 95\% CI [1.04-1.35]) and CV mortality (HR 1.25, 95\% CI [1.06-1.47])

After adjustment for demographic, randomization, CVD, and kidney disease factors, $\mathrm{HR}=1.09$ with a trend toward statistical significance

\begin{tabular}{|c|c|c|c|c|c|c|c|}
\hline $\begin{array}{l}\text { Abedini } \\
\text { et al. [118] }\end{array}$ & ADMA & 2,102 & $\begin{array}{l}2,102 \text { kidney } \\
\text { transplant } \\
\text { recipients from } \\
\text { the ALERT } \\
\text { study }\end{array}$ & $\begin{array}{l}\text { Mean: } 6.7 \\
\text { years }\end{array}$ & ADMA & $\begin{array}{l}\text { Renal endpoint: the } \\
\text { time to graft failure } \\
\text { or doubling SCr } \\
\text { MACE (cardiac } \\
\text { death, nonfatal MI, } \\
\text { or coronary } \\
\text { intervention } \\
\text { procedure) } \\
\text { Cerebrovascular } \\
\text { event (fatal and } \\
\text { nonfatal stroke) } \\
\text { All-cause mortality }\end{array}$ & $\begin{array}{l}\text { The number of renal, MACE, cerebrovascular, } \\
\text { and all-cause mortality endpoints increased } \\
\text { significantly by ADMA quartiles } \\
\text { ADMA was an independent predictor of renal } \\
\text { endpoint (HR } 2.78,95 \% \text { CI [1.22-5.82]), } \\
\text { MACE (HR } 2.61,95 \% \text { CI }[1.03-6.61]) \text {, } \\
\text { cerebrovascular events (HR } 6.63,95 \% \text { CI } \\
\text { [2.52-23.13]), and all-cause mortality (HR } \\
4.87,95 \% \text { CI }[2.12-11.18] \text { ) }\end{array}$ \\
\hline $\begin{array}{l}\text { Shi } \\
\text { et al. [109] }\end{array}$ & ADMA & 76 & $\begin{array}{l}76 \text { CKD } \\
\text { patients and } \\
15 \text { controls }\end{array}$ & $\begin{array}{l}15(6-24) \\
\text { months }\end{array}$ & $\begin{array}{l}\text { ADMA } \\
\text { LVMI }\end{array}$ & CV events & $\begin{array}{l}\text { ADMA: independent marker of LVMI } \\
\text { ADMA was an independent risk factor for CV } \\
\text { events (HR }=1.18,95 \% \mathrm{CI}[1.07-1.29])\end{array}$ \\
\hline
\end{tabular}


Table 5 (continued)

\begin{tabular}{|c|c|c|c|c|c|c|c|}
\hline Study & $\begin{array}{l}\text { Bio- } \\
\text { marker }\end{array}$ & $N$ & Participants & $\begin{array}{l}\text { Follow-up } \\
\text { duration }\end{array}$ & Study variables & Outcome & Results \\
\hline $\begin{array}{l}\mathrm{Lu} \\
\text { et al. [114] }\end{array}$ & ADMA & 298 & $\begin{array}{l}298 \text { CKD stage } \\
3-4 \text { patients }\end{array}$ & $2.9 \pm 1.2$ years & ADMA & $\begin{array}{l}\text { All-cause mortality } \\
\text { Combined: all- } \\
\text { cause mortality, } \\
\text { nonfatal MI, or } \\
\text { stroke }\end{array}$ & $\begin{array}{l}\uparrow \uparrow \text { ADMA in patients who showed all-cause } \\
\text { death and the composite outcome. ROC } \\
\text { analysis } \rightarrow \text { ADMA cutoff point }=0.47 \mu \mathrm{mol} / \mathrm{L} \\
\text { for all-cause death and composite outcome } \\
\text { Multivariate analysis } \\
\text { ADMA }>0.47 \text { versus } \leq 0.47 \mu \mathrm{mol} / \mathrm{L} \text { was } \\
\text { associated with increased risk of all-cause } \\
\text { mortality (HR } 2.87,95 \% \text { CI }[1.14-7.22] \text { ) and } \\
\text { the combined outcome (HR } 2.45,95 \% \mathrm{CI} \\
{[1.18-5.09] \text { ) }} \\
\text { ADMA (as continuous variable) was } \\
\text { associated with the combined outcome (HR } \\
1.37,95 \% \mathrm{CI}[1.09-1.73] \text { ) }\end{array}$ \\
\hline
\end{tabular}

\begin{tabular}{llllll}
\hline $\begin{array}{l}\text { Kanbay } \\
\text { et al. [113] }\end{array}$ & ADMA 259 & $\begin{array}{l}\text { 259 CKD stage } \\
1-5 \text { patients }\end{array}$ & $\begin{array}{l}\text { Median of } \\
38 \text { months }\end{array}$ & $\begin{array}{l}\text { ADMA } \\
\text { Uric acid } \\
\text { FMD }\end{array}$ & $\begin{array}{l}\text { All-cause mortality } \\
\text { CV events (CV } \\
\text { mortality, nonfatal } \\
\text { MI, or stroke) } \\
\text { Combined outcome }\end{array}$ \\
& & & & &
\end{tabular}

Univariate analysis, uric acid, and ADMA $>$ median $\rightarrow \uparrow$ risk all-cause mortality (HR $5.06,95 \%$ CI [2.01-12.76]), CV events (HR $4.75,95 \%$ CI [2.98-7.59]), and the composite Combined outcome outcome (HR 4.13, 95\% CI [2.66-6.43])

After adjustment for renal-specific risk factors (GFR, proteinuria, and hsCRP) $\rightarrow$ this association only for $\mathrm{CV}$ and composite outcome

Addition of uric acid and ADMA into a model with traditional and renal-specific risk factors $\rightarrow$ not increase the prediction ability for none of the outcomes

\begin{tabular}{|c|c|c|c|c|c|c|}
\hline $\begin{array}{l}\text { Amabile } \\
\text { et al. [135] }\end{array}$ & EMPs & 81 & 81 hemodialysis & $\begin{array}{l}50.5 \text { months } \\
(5-72)\end{array}$ & $\begin{array}{l}\text { Microparticles } \\
\text { (platelet-derived } \\
\text { MPs, } \\
\text { erythrocyte- } \\
\text { derived MPs, } \\
\text { EMPs: } \\
\text { leukocytes MPs) } \\
\text { Framingham } \\
\text { and European } \\
\text { SCORE }\end{array}$ & $\begin{array}{l}\text { All-cause mortality } \\
\text { CV mortality (fatal } \\
\text { MI, stroke, acute } \\
\text { pulmonary edema, } \\
\text { and sudden death) } \\
\text { MACE (nonfatal } \\
\text { ACS, stroke, acute } \\
\text { pulmonary edema, } \\
\text { and arrhythmias) }\end{array}$ \\
\hline
\end{tabular}

EMPs (separated in tertiles): significant differences in CV $(\log$-rank $p<0.01)$ and all-cause mortality $(\log$-rank $p<0.001)$ All-cause mortality Multivariate analysis: age (HR 1.10, 95\% CI [1.02-1.19]) and EMPs (HR 21.7, 95\% CI [4.23-111.18]) were independent predictors CV mortality Multivariate analysis: age (HR 1.09, 95\% CI [1.02-1.16]) and EMPs (HR 20.0, 95\% CI [3.86-103.5]) were independent predictors MACE

Multivariate analysis: history of CVD (HR $7.15,95 \%$ CI $[2.33,20.0]$ ), age (HR 1.06, 95\% CI [1.02-1.10]), and EMPs (HR 5.03, 95\% CI [1.67-15.15]) were independent predictors

\begin{tabular}{|c|c|c|c|c|c|c|}
\hline $\begin{array}{l}\text { Carmona } \\
\text { et al. [138] }\end{array}$ & EMPs & 160 & $\begin{array}{l}160 \\
\text { hemodialysis } \\
\text { ( } 80 \text { with DM } \\
\text { and } 80 \text { without } \\
\text { DM) }\end{array}$ & 5.5 years & $\begin{array}{l}\text { EMPs } \\
\text { Monocyte } \\
\text { subpopulations } \\
\text { Ang-1, Ang-2 }\end{array}$ & All-cause mortality \\
\hline
\end{tabular}

EMPs level, monocyte subpopulations (CD14/
CD162 and CD142/CD16), and Ang-2-toAng-1 ratios increased in patients with DM compared with non-DM

EMP level $<$ median $\rightarrow$ improved survival versus EMP levels $>$ median $(\log$-rank $p<$ $0.001)$. Similar significant associations observed in subgroup analyses (DM and non-DM)

After adjustment for DM and traditional CV risk factors, EMP level $>$ median $\rightarrow \uparrow$ all-cause mortality (HR 2.36, 95\% CI [1.40-4.01]) 
Table 5 (continued)

\begin{tabular}{|c|c|c|c|c|c|c|c|}
\hline Study & $\begin{array}{l}\text { Bio- } \\
\text { marker }\end{array}$ & $N$ & Participants & $\begin{array}{l}\text { Follow-up } \\
\text { duration }\end{array}$ & Study variables & Outcome & Results \\
\hline $\begin{array}{l}\text { Green } \\
\text { et al. [139] }\end{array}$ & EMPs & 123 & $\begin{array}{l}123 \text { CKD stage } \\
3-5 \text { patients }\end{array}$ & $3.9 \pm 2.2$ years & $\begin{array}{l}\text { EMPs } \\
\text { SEMPs } \\
\text { (longitudinal } \\
\text { EMP change) }\end{array}$ & $\begin{array}{l}\text { All-cause mortality } \\
\text { MACE (including } \\
\text { MI, stroke, CABG, } \\
\text { limb amputation } \\
\text { for ischemic } \\
\text { reason, } \\
\text { noncoronary } \\
\text { revascularization, } \\
\text { and hospitalization } \\
\text { for heart failure or } \\
\text { CV death) } \\
\text { RRT (dialysis or } \\
\text { transplantation) }\end{array}$ & $\begin{array}{l}\text { All-cause mortality } \\
\text { Univariate analysis: EMP (HR 3.31, 95\% CI } \\
{[1.12-9.76] \text { ) and not } \delta \text { EMP (HR 0.64, } 95 \% \text { CI }} \\
{[0.21-1.94] \text { ) associated with death. Other }} \\
\text { parameters that were associated: age, DM, } \\
\text { Karnofsky score, eGFR, PTH, CRP, and } \\
\text { hemoglobin } \\
\text { Multivariate analysis: EMP (HR } 8.20,95 \% \text { CI } \\
{[1.67-40.2] \text { ), age, and eGFR were significantly }} \\
\text { associated. } \delta \text { EMP was not significantly } \\
\text { associated (HR 2.69, } 95 \% \text { CI [0.04-165]) } \\
\text { MACE or CV death } \\
\text { Univariate analysis: age was associated (HR } \\
1.05 \text { [1.00-1.09]) } \\
\text { Multivariate analysis: none of the parameters } \\
\text { showed significance } \\
R R T \\
\text { Univariate analysis: none of the parameters } \\
\text { showed significance } \\
\text { Multivariate analysis: albumin was an } \\
\text { independent predictor (HR } 0.90,95 \% \text { CI } \\
{[0.83-0.98] \text { ) }}\end{array}$ \\
\hline
\end{tabular}

ADMA, asymmetric dimethylarginine; Ang, angiopoietin; ACS, acute coronary syndrome; CKD, chronic kidney disease; CABG, coronary artery bypass grafting; CVD, cardiovascular disease; CV, cardiovascular; CRP, C-reactive protein; DM, diabetes mellitus; EMPs, endothelial microparticles; ESRD, endstage renal disease; FMD, flow-mediated dilatation; GFR, glomerular filtration rate; LVMI, left ventricular mass index; MPs, microparticles; MACE, major adverse cardiovascular events; MI, myocardial infarction; PTH, parathormone; RRT, renal replacement therapy; SCr, serum creatinine.

and found that EMPs were significantly higher in CKD patients than in healthy controls and that uremic toxins induced high levels of EMP release. In a study in CKD patients under different dialysis modalities, EMP levels were increased only in nondialysis and hemodialysis patients and not in the peritoneal dialysis group and controls [134]. In a previous study, Amabile et al. [135] demonstrated that EMP levels are inversely correlated with FMD and also with increased pulse wave velocity (PWV) and augmentation index; impairment of NO release was proposed as the mechanism through which EMPs impair endothelium-dependent vasodilation [136]. A pediatric study yielded similar results; EMPs were found to be strongly correlated with cIMT and PWV in children with predialysis CKD and ESKD [137].

With regard to outcome prediction (Table 5) in the aforementioned prospective cohort study of Amabile et al. [136] in 81 hemodialysis subjects, patients with higher levels of EMPs had significantly higher probability of cardiovascular and total death; EMP levels were independent predictors of cardiovascular outcomes and all-cause mortality after adjustment for confounding factors. Similar observations were made in another study in 160 hemodi- alysis patients; EMP levels above the median were associated with increased all-cause mortality, after adjustment for diabetes and other traditional cardiovascular risk factors [138]. Despite the associations of EMPs with hard outcomes, the longitudinal EMP change was not associated with mortality [139].

\section{Arterial Glycocalyx Breakdown Products}

Apart from functional methods to assess the integrity of arterial glycocalyx discussed above, estimates of glycocalyx's breakdown products (e.g., heparan sulfate, syndecan-1, and hyaluronan) through serum assays provide a readily assessable and reliable measure of glycocalyx dysfunction [65]. Few studies have examined the levels of such markers in CKD. In the aforementioned study of Vlahu et al. [67], hemodialysis patients had increased levels of syndecan-1 and hyaluronan. In a following study, Padberg et al. [140] demonstrated a robust inverse association between renal function and serum levels of syndecan-1 and hyaluronan in a cohort of different stage CKD patients. Finally, in a cohort study including 84 hemodialysis patients, lower syndecan-1 levels were associated with cardiovascular events and total mortality [141]. 


\section{Biomarkers of Inflammation}

Following a well-established, bidirectional association between endothelial dysfunction and inflammation, the circulating levels of biomarkers of inflammation parallel the severity of endothelial dysfunction. This category includes several markers, including CRP, interleukins (ILs), tumor necrosis factor-alpha (TNF- $\alpha$ ), TNF-like weak inducer of apoptosis (TWEAK), pentraxin 3 (PTX3), monocyte chemoattractant protein-1 (MCP-1), and others, that have been variably used in studies in CKD that have also evaluated endothelial function. In a study including 38 non-dialysis, 18 hemodialysis, and 22 kidney transplant patients and 65 healthy controls, CRP was higher in the CKD group compared to controls, and it was significantly correlated with FMD and cIMT; hemodialysis patients had the highest CRP of all CKD groups studied [34]. In a cohort study of 403 subjects with stage 1-5 CKD, IL-10 levels increased along with the reduction of kidney function and FMD, while higher IL-10 levels were associated with cardiovascular events [40]. Both PTX3 and TWEAK levels are associated with the endothelial dysfunction observed with progressive kidney failure, as well as with cardiovascular events [142]. TNF- $\alpha$ and MCP-1 were also shown to be significantly higher in CKD patients with established cardiovascular disease [143].

\section{Conclusions}

Cardiovascular disease is the main cause of death in $\mathrm{CKD}$ with many traditional and nontraditional risk factors playing important roles in its development. Through the years, noninvasive functional methods, most commonly VOP and FMD, have been used to assess endothelial dysfunction in patients with CKD and examine associations with clinical outcomes. In addition, several studies have used biomarkers of endothelial function, most commonly ADMA and cell adhesion molecules, to investigate such associations. Accumulated evidence from such works suggests that endothelial dysfunction occurs in the early stages of CKD and deteriorates with eGFR reduction. Furthermore, in several observational studies, impaired endothelial function was shown to be associated with markers of target organ damage (i.e., LVH, cIMT, or albuminuria) in these subjects. In addition, a few cohort studies indicate that endothelial dysfunction is associated with cardiovascular events and mortality and progression of CKD toward ESKD. Despite the above data on the relationship of endothelial dysfunction with cardiovascular or kidney disease progression, the use of endothelial dys- function markers in prediction of cardiovascular outcomes is currently far away from clinical practice. Future studies examining the value of adding relevant markers on available risk scores for cardiovascular risk prediction could be particularly useful. Moreover, over the last years, novel, noninvasive methods evaluating microvascular function, such as LSCI, video capillaroscopy, and NIRS, are increasingly used, but studies in CKD patients are still scarce. As such methods can offer a detailed, real-time assessment of various factors related to vascular function, such as changes in blood flow, capillary recruitment, and tissue oxygenation, and can be easily combined with standardized procedures for vascular reactivity testing (arterial and venous occlusions, exercise, and others), future studies with proper design and adequate power can open new avenues of valuable information on the precise roles of endothelial dysfunction on cardiovascular and renal disease progression in patients with CKD.

\section{Conflict of Interest Statement}

All authors disclose that they do not have any financial or other relationships, which might lead to a conflict of interest regarding this paper.

\section{Funding Sources}

This paper was not supported by any source and represents an original effort of the authors.

\section{Author Contributions}

M.T. and M.S.: manuscript drafting; P.S.: conception and critical revision of the manuscript.

\begin{tabular}{|c|c|}
\hline References & $\begin{array}{l}1 \text { Aird WC. Phenotypic heterogeneity of the en- } \\
\text { dothelium: I. Structure, function, and mecha- } \\
\text { nisms. Circ Res. } 2007 \text { Feb;100(2):158-73. } \\
2 \text { Flammer AJ, Anderson T, Celermajer DS, } \\
\text { Creager MA, Deanfield J, Ganz P, et al. The } \\
\text { assessment of endothelial function: from re- } \\
\text { search into clinical practice. Circulation. } 2012 \\
\text { Aug;126(6):753-67. } \\
3 \text { Jourde-Chiche N, Fakhouri F, Dou L, Bellien } \\
\text { J, Burtey S, Frimat M, et al. Endothelium } \\
\text { structure and function in kidney health and } \\
\text { disease. Nat Rev Nephrol. 2019;15(2):87-108. } \\
4 \text { Saran R, Robinson B, Abbott KC, Bragg- } \\
\text { Gresham J, Chen X, Gipson D, et al. US renal } \\
\text { data system } 2019 \text { annual data report: epide- } \\
\text { miology of kidney disease in the United } \\
\text { States. Am J Kidney Dis. 2020;75(1):A6-7. }\end{array}$ \\
\hline
\end{tabular}


5 Elsevier. Chapter 3: morbidity and mortality in patients with CKD. Am J Kidney Dis. 2019 Mar;73(3):S45-78.

6 Go AS, Chertow GM, Fan D, McCulloch CE, Hsu CY. Chronic kidney disease and the risks of death, cardiovascular events, and hospitalization. N Engl J Med. 2004 Sep 23;351(13): 1296-305.

7 Saran R, Li Y, Robinson B, Abbott KC, Agodoa LY, Ayanian J, et al. US renal data system 2015 annual data report: epidemiology of kidney disease in the United States. Am J Kidney Dis. 2016 Mar;67(3 Suppl 1):Svii,

8 Fliser D, Wiecek A, Suleymanlar G, Ortiz A, Massy Z, Lindholm B, et al. The dysfunctional endothelium in CKD and in cardiovascular disease: mapping the origin(s) of cardiovascular problems in CKD and of kidney disease in cardiovascular conditions for a research agenda. Kidney Int Suppl. 2011 Jun;1(1):6-9.

9 Malyszko J. Mechanism of endothelial dysfunction in chronic kidney disease. Clin Chim Acta. 2010 Oct;411(19-20):1412-20.

10 Kang DH, Kanellis J, Hugo C, Truong L, Anderson S, Kerjaschki D, et al. Role of the microvascular endothelium in progressive renal disease. J Am Soc Nephrol. 2002 Mar;13(3): 806-16.

11 Hogas SM, Voroneanu L, Serban DN, Segal L, Hogas MM, Serban IL, et al. Methods and potential biomarkers for the evaluation of endothelial dysfunction in chronic kidney disease: a critical approach. J Am Soc Hypertens. 2010 Jun;4(3):116-27.

12 Wilkinson IB, Webb DJ. Venous occlusion plethysmography in cardiovascular research: methodology and clinical applications. Br J Clin Pharmacol. 2001 Dec;52(6):631-46.

13 Maruhashi T, Kihara Y, Higashi Y. Assessment of endothelium-independent vasodilation: from methodology to clinical perspectives. J Hypertens. 2018;36(7):1460-7.

14 Lekakis J, Abraham P, Balbarini A, Blann A, Boulanger CM, Cockcroft J, et al. Methods for evaluating endothelial function: a position statement from the European Society of Cardiology Working Group on peripheral circulation. Eur J Cardiovasc Prev Rehabil. 2011 Dec;18(6):775-89.

15 Gliemann L, Mortensen SP, Hellsten Y. Methods for the determination of skeletal muscle blood flow: development, strengths and limitations. Eur J Appl Physiol. 2018 Jun;118(6): 1081-94.

16 Passauer J, Pistrosch F, Lässig G, Herbrig K, Büssemaker E, Gross P, et al. Nitric oxide- and EDHF-mediated arteriolar tone in uremia is unaffected by selective inhibition of vascular cytochrome P450 2C9. Kidney Int. 2005 May; 67(5):1907-12.

17 Passauer J, Büssemaker E, Lassig G, Gross P Kidney transplantation improves endothelium-dependent vasodilation in patients with endstage renal disease. Transplantation. 2003 Jun;75(11):1907-10.

18 Dember LM, Imrey PB, Duess MA, Hamburg NM, Larive B, Radeva M, et al. Vascular func- tion at baseline in the hemodialysis fistula maturation study. J Am Heart Assoc. 2016 22; 5(7):5.

19 Pannier B, Guerin AP, Marchais SJ, Metivier F, Safar ME, London GM. Postischemic vasodilation, endothelial activation, and cardiovascular remodeling in end-stage renal disease. Kidney Int. 2000 Mar;57(3):1091-9.

20 Briese S, Wiesner S, Will JC, Lembcke A, Op gen-Rhein B, Nissel R, et al. Arterial and cardiac disease in young adults with childhoodonset end-stage renal disease-impact of calcium and vitamin D therapy. Nephrol Dial Transplant. 2006 Jul;21(7):1906-14.

21 Annuk M, Soveri I, Zilmer M, Lind L, Hulthe J, Fellström B. Endothelial function, CRP and oxidative stress in chronic kidney disease. J Nephrol. 2005 Dec;18(6):721-6.

22 London GM, Pannier B, Agharazii M, Guerin AP, Verbeke FH, Marchais SJ. Forearm reactive hyperemia and mortality in end-stage renal disease. Kidney Int. 2004 Feb;65(2):700-4.

23 Perticone F, Maio R, Perticone M, Sciacqua A, Shehaj E, Naccarato P, et al. Endothelial dysfunction and subsequent decline in glomerular filtration rate in hypertensive patients. Circulation. 2010 Jul;122(4):379-84.

24 Khatir DS, Pedersen M, Ivarsen P, Christensen KL, Jespersen B, Buus NH. Effects of additional vasodilatory or nonvasodilatory treatment on renal function, vascular resistance and oxygenation in chronic kidney disease: a randomized clinical trial. J Hypertens. 2019;37(1):116-24.

25 Flevari P, Kalogeropoulou S, Drakou A, Leftheriotis D, Panou F, Lekakis J, et al. Spironolactone improves endothelial and cardiac autonomic function in non heart failure hemodialysis patients. J Hypertens. 2013 Jun; 31(6):1239-44.

26 Raitakari OT, Celermajer DS. Flow-mediated dilatation. Br J Clin Pharmacol. 2000 Nov; 50(5):397-404.

27 Stout M. Flow-mediated dilatation: a review of techniques and applications. Echocardiography. 2009 Aug;26(7):832-41.

28 Corretti MC, Anderson TJ, Benjamin EJ, Celermajer D, Charbonneau F, Creager MA, et al. Guidelines for the ultrasound assessment of endothelial-dependent flow-mediated vasodilation of the brachial artery: a report of the International Brachial Artery Reactivity Task Force. J Am Coll Cardiol. 2002 Jan;39(2):25765.

29 Deanfield J, Donald A, Ferri C, Giannattasio C, Halcox J, Halligan S, et al. Endothelial function and dysfunction. Part I: methodological issues for assessment in the different vascular beds: a statement by the Working Group on Endothelin and Endothelial Factors of the European Society of Hypertension. J Hypertens. 2005 Jan;23(1):7-17.

30 Anderson TJ, Gerhard MD, Meredith IT, Charbonneau F, Delagrange D, Creager MA, et al. Systemic nature of endothelial dysfunction in atherosclerosis. Am J Cardiol. 1995 Feb;75(6):71B-4B.
31 Dogra G, Irish A, Chan D, Watts G. Insulin resistance, inflammation, and blood pressure determine vascular dysfunction in CKD. Am J Kidney Dis. 2006 Dec;48(6):926-34.

32 Sharma J, Kapoor A, Muthu R, Prasad N, Sinha A, Khanna R, et al. Assessment of endothelial dysfunction in Asian Indian patients with chronic kidney disease and changes following renal transplantation. Clin Transplant. 2014 Aug;28(8):889-96.

33 Yilmaz MI, Stenvinkel P, Sonmez A, Saglam M, Yaman H, Kilic S, et al. Vascular health, systemic inflammation and progressive reduction in kidney function; clinical determinants and impact on cardiovascular outcomes. Nephrol Dial Transplant. 2011 Nov; 26(11):3537-43.

34 Recio-Mayoral A, Banerjee D, Streather C, Kaski JC. Endothelial dysfunction, inflammation and atherosclerosis in chronic kidney disease: a cross-sectional study of predialysis, dialysis and kidney-transplantation patients. Atherosclerosis. 2011 Jun;216(2):446-51.

35 Lilitkarntakul P, Dhaun N, Melville V, Blackwell S, Talwar DK, Liebman B, et al. Blood pressure and not uraemia is the major determinant of arterial stiffness and endothelial dysfunction in patients with chronic kidney disease and minimal co-morbidity. Atherosclerosis. 2011 May;216(1):217-25.

36 Yilmaz MI, Sonmez A, Saglam M, Yaman H, Kilic S, Turker T, et al. Longitudinal analysis of vascular function and biomarkers of metabolic bone disorders before and after renal transplantation. Am J Nephrol. 2013;37(2): $126-34$.

37 Verbeke FH, Pannier B, Guérin AP, Boutouyrie P, Laurent S, London GM. Flow-mediated vasodilation in end-stage renal disease. Clin J Am Soc Nephrol. 2011 Aug;6(8):2009-15.

38 Poulikakos D, Ross L, Recio-Mayoral A, Cole $\mathrm{D}$, Andoh J, Chitalia N, et al. Left ventricular hypertrophy and endothelial dysfunction in chronic kidney disease. Eur Heart J Cardiovasc Imaging. 2014 Jan;15(1):56-61.

39 Dubin RF, Guajardo I, Ayer A, Mills C, Donovan C, Beussink L, et al. Associations of macro- and microvascular endothelial dysfunction with subclinical ventricular dysfunction in end-stage renal disease. Hypertension. 2016;68(4):913-20.

40 Yilmaz MI, Solak Y, Saglam M, Cayci T, Acikel C, Unal HU, et al. The relationship between IL-10 levels and cardiovascular events in patients with CKD. Clin J Am Soc Nephrol. $2014 \mathrm{Jul} ; 9(7): 1207-16$.

41 Gungor O, Unal HU, Guclu A, Gezer M, Eyileten T, Guzel FB, et al. IL-33 and ST2 levels in chronic kidney disease: associations with inflammation, vascular abnormalities, cardiovascular events, and survival. PLoS One. 2017;12(6):e0178939.

42 Kanbay M, Siriopol D, Saglam M, Kurt YG Gok M, Cetinkaya H, et al. Serum sclerostin and adverse outcomes in nondialyzed chronic kidney disease patients. J Clin Endocrinol Metab. 2014 Oct;99(10):E1854-61. 
43 Yilmaz MI, Sonmez A, Saglam M, Gulec M, Kilic S, Eyileten T, et al. Hemoglobin is inversely related to flow-mediated dilatation in chronic kidney disease. Kidney Int. 2009 Jun; 75(12):1316-21.

44 Chan DT, Watts GF, Irish AB, Dogra GK. Rosiglitazone does not improve vascular function in subjects with chronic kidney disease. Nephrol Dial Transplant. 2011 Nov; 26(11):3543-9.

45 Dogra G, Irish A, Chan D, Watts G. A randomized trial of the effect of statin and fibrate therapy on arterial function in CKD. Am J Kidney Dis. 2007 Jun;49(6):776-85.

46 Thethi TK, Bajwa MA, Ghanim H, Jo C, Weir $M$, Goldfine $A B$, et al. Effect of paricalcitol on endothelial function and inflammation in type 2 diabetes and chronic kidney disease. J Diabetes Complicat. 2015 Apr;29(3):433-7.

$47 \mathrm{Hu} \mathrm{C}, \mathrm{Wu} \mathrm{X}$. Effect of vitamin D supplementation on vascular function and inflammation in patients with chronic kidney disease: a controversial issue. Ther Apher Dial. 2019 Aug.

48 Bellien J, Fréguin-Bouilland C, Joannidès R, Hanoy M, Rémy-Jouet I, Monteil C, et al. High-efficiency on-line haemodiafiltration improves conduit artery endothelial function compared with high-flux haemodialysis in end-stage renal disease patients. Nephrol Dial Transplant. 2014 Feb;29(2):414-22.

49 Babos L, Járai Z, Nemcsik J. Evaluation of microvascular reactivity with laser Doppler flowmetry in chronic kidney disease. World J Nephrol. 2013 Aug;2(3):77-83.

50 Kalia YN, Naik A, Garrison J, Guy RH. Iontophoretic drug delivery. Adv Drug Deliv Rev. 2004 Mar;56(5):619-58.

51 Low DA, Jones H, Cable NT, Alexander LM, Kenney WL. Historical reviews of the assessment of human cardiovascular function: interrogation and understanding of the control of skin blood flow. Eur J Appl Physiol. 2020 Jan;120(1):1-16.

52 Strisciuglio T, De Luca S, Capuano E, Luciano R, Niglio T, Trimarco B, et al. Endothelial dysfunction: its clinical value and methods of assessment. Curr Atheroscler Rep. 2014 Jun; 16(6):417.

53 Seliger SL, Salimi S, Pierre V, Giffuni J, Katzel L, Parsa A. Microvascular endothelial dysfunction is associated with albuminuria and CKD in older adults. BMC Nephrol. 2016 13; 17(1):82.

54 Thang OH, Serné EH, Grooteman MP, Smulders YM, Ter Wee PM, Tangelder GJ, et al. Premature aging of the microcirculation in patients with advanced chronic kidney disease. Nephron Extra. 2012 Jan;2(1):283-92.

55 Kirkman DL, Muth BJ, Ramick MG, Townsend RR, Edwards DG. Role of mitochondria-derived reactive oxygen species in microvascular dysfunction in chronic kidney disease. Am J Physiol Renal Physiol. 2018 Mar;314(3):F423-9.

56 Farkas K, Nemcsik J, Kolossváry E, Járai Z, Nádory E, Farsang C, et al. Impairment of skin microvascular reactivity in hypertension and uraemia. Nephrol Dial Transplant. 2005 Sep;20(9):1821-7.

57 Nemcsik J, Cseprekál O, Egresits J, Kielstein J, Kümpers P, Lukasz A, et al. The role of laser Doppler flowmetry tests, serum angiopoietin-2, asymmetric and symmetric dimethylarginine to predict outcome in chronic kidney disease. J Hypertens. 2017;35(5):1109-18.

58 Kruger A, Stewart J, Sahityani R, O’Riordan E, Thompson C, Adler S, et al. Laser Doppler flowmetry detection of endothelial dysfunction in end-stage renal disease patients: correlation with cardiovascular risk. Kidney Int. 2006 Jul;70(1):157-64.

59 Stewart J, Kohen A, Brouder D, Rahim F, Adler S, Garrick R, et al. Noninvasive interrogation of microvasculature for signs of endothelial dysfunction in patients with chronic renal failure. Am J Physiol Heart Circ Physiol. 2004 Dec;287(6):H2687-96.

60 Kirkman DL, Ramick MG, Muth BJ, Stock JM, Pohlig RT, Townsend RR, et al. Effects of aerobic exercise on vascular function in nondialysis chronic kidney disease: a randomized controlled trial. Am J Physiol Renal Physiol. 2019 Apr;316(5):F898-905.

61 Nieuwdorp M, van Haeften TW, Gouverneur MC, Mooij HL, van Lieshout MH, Levi M, et al. Loss of endothelial glycocalyx during acute hyperglycemia coincides with endothelial dysfunction and coagulation activation in vivo. Diabetes. 2006 Feb;55(2):480-6.

62 Uchimido R, Schmidt EP, Shapiro NI. The glycocalyx: a novel diagnostic and therapeutic target in sepsis. Crit Care. 2019 Jan;23(1):16.

63 Cerny V, Astapenko D, Burkovskiy I, Hyspler $\mathrm{R}$, Ticha A, Trevors MA, et al. Glycocalyx in vivo measurement. Clin Hemorheol Microcirc. 2017;67(3-4):499-503.

64 Nieuwdorp M, Meuwese MC, Mooij HL, Ince C, Broekhuizen LN, Kastelein JJ, et al. Measuring endothelial glycocalyx dimensions in humans: a potential novel tool to monitor vascular vulnerability. J Appl Physiol. 2008 Mar;104(3):845-52.

65 Liew H, Roberts MA, MacGinley R, McMahon LP. Endothelial glycocalyx in health and kidney disease: rising star or false dawn? Nephrology. 2017 Dec;22(12):940-6.

66 Salmon AH, Ferguson JK, Burford JL, Gevorgyan $\mathrm{H}$, Nakano D, Harper SJ, et al. Loss of the endothelial glycocalyx links albuminuria and vascular dysfunction. J Am Soc Nephrol. 2012 Aug;23(8):1339-50.

67 Vlahu CA, Lemkes BA, Struijk DG, Koopman MG, Krediet RT, Vink H. Damage of the endothelial glycocalyx in dialysis patients. J Am Soc Nephrol. 2012 Nov;23(11):1900-8.

68 Tew GA, Klonizakis M, Crank H, Briers JD, Hodges GJ. Comparison of laser speckle contrast imaging with laser Doppler for assessing microvascular function. Microvasc Res. 2011 Nov;82(3):326-32.

69 Hecht N, Woitzik J, Dreier JP, Vajkoczy P. Intraoperative monitoring of cerebral blood flow by laser speckle contrast analysis. Neurosurg Focus. 2009 Oct;27(4):E11.
70 Mennes OA, van Netten JJ, van Baal JG, Steenbergen W. Assessment of microcirculation in the diabetic foot with laser speckle contrast imaging. Physiol Meas. 2019 1;40(6):065002.

71 de M Matheus AS, Clemente EL, de Lourdes Guimarães Rodrigues M, Torres Valença DC, Gomes MB. Assessment of microvascular endothelial function in type 1 diabetes using laser speckle contrast imaging. J Diabetes Complicat. 2017 Apr;31(4):753-7.

72 Borges JP, Lopes GO, Verri V, Coelho MP, Nascimento PM, Kopiler DA, et al. A novel effective method for the assessment of microvascular function in male patients with coronary artery disease: a pilot study using laser speckle contrast imaging. Braz J Med Biol Res. 2016 Sep;49(10):e5541.

73 Alexandrou ME, Gkaliagkousi E, Loutradis C, Dimitriadis C, Mitsopoulos E, Lazaridis A, et al. Hemodialysis and peritoneal dialysis patients have severely impaired post-occlusive skin forearm vasodilatory response assessed with laser speckle contrast imaging. Clin Kidney J. 2020 [in press].

74 Triantafyllou A, Anyfanti P, Pyrpasopoulou A, Triantafyllou G, Aslanidis S, Douma S. Capillary rarefaction as an index for the microvascular assessment of hypertensive patients. Curr Hypertens Rep. 2015 May; 17(5):33.

75 Antonios TF, Singer DR, Markandu ND, Mortimer PS, MacGregor GA. Structural skin capillary rarefaction in essential hypertension. Hypertension. 1999 Apr;33(4):998-1001.

76 Schoina M, Loutradis C, Memmos E, Dimitroulas T, Pagkopoulou E, Doumas M, et al. Microcirculatory function deteriorates with advancing stages of chronic kidney disease independently of arterial stiffness and atherosclerosis. Hypertens Res. 2020 Jul 29.

77 Serné EH, Gans RO, ter Maaten JC, Tangelder GJ, Donker AJ, Stehouwer CD. Impaired skin capillary recruitment in essential hypertension is caused by both functional and structural capillary rarefaction. Hypertension. 2001 Aug;38(2):238-42.

78 Thang OH, Serné EH, Grooteman MP, Smulders YM, ter Wee PM, Tangelder GJ, et al. Capillary rarefaction in advanced chronic kidney disease is associated with high phosphorus and bicarbonate levels. Nephrol Dial Transplant. 2011 Nov;26(11):3529-36.

79 Edwards-Richards A, DeFreitas M, Katsoufis $\mathrm{CP}$, Seeherunvong W, Sasaki N, Freundlich M, et al. Capillary rarefaction: an early marker of microvascular disease in young hemodialysis patients. Clin Kidney J. 2014 Dec;7(6):569-74.

80 Lundwall K, Jörneskog G, Jacobson SH, Spaak J. Paricalcitol, microvascular and endothelial function in non-diabetic chronic kidney disease: a randomized trial. Am J Nephrol. 2015; 42(4):265-73.

81 Nissel R, Fischer DC, Puhlmann A, HoldtLehmann B, Mitzner A, Petzsch M, et al. Short-term growth hormone treatment and microcirculation: effects in patients with chronic kidney disease. Microvasc Res. 2009 Sep;78(2):246-52. 
82 Jones S, Chiesa ST, Chaturvedi N, Hughes AD. Recent developments in near-infrared spectroscopy (NIRS) for the assessment of local skeletal muscle microvascular function and capacity to utilise oxygen. Artery Res. 2016 Dec;16:25-33.

83 Dipla K, Triantafyllou A, Koletsos N, Papadopoulos S, Sachpekidis V, Vrabas IS, et al. Impaired muscle oxygenation and elevated exercise blood pressure in hypertensive patients: links with vascular stiffness. Hypertension. 2017;70(2):444-51.

84 Anyfanti P, Triantafyllidou E, Papadopoulos S, Triantafyllou A, Nikolaidis MG, Kyparos A, et al. Smoking before isometric exercise amplifies myocardial stress and dysregulates baroreceptor sensitivity and cerebral oxygenation. J Am Soc Hypertens. 2017 Jun;11(6): 376-84.

85 Dipla K, Triantafyllou A, Grigoriadou I, Kintiraki E, Triantafyllou GA, Poulios P, et al. Impairments in microvascular function and skeletal muscle oxygenation in women with gestational diabetes mellitus: links to cardiovascular disease risk factors. Diabetologia. 2017;60(1):192-201.

86 Waksman R, Torguson R, Spad MA, GarciaGarcia H, Ware J, Wang R, et al. The LipidRich Plaque Study of vulnerable plaques and vulnerable patients: study design and rationale. Am Heart J. 2017 Oct;192:98-104.

87 Manfredini F, Lamberti N, Malagoni AM, Felisatti $\mathrm{M}$, Zuccalà $\mathrm{A}$, Torino $\mathrm{C}$, et al. The role of deconditioning in the end-stage renal disease myopathy: physical exercise improves altered resting muscle oxygen consumption. Am J Nephrol. 2015;41(4-5):329-36.

88 Wilkinson TJ, White AEM, Nixon DGD, Gould DW, Watson EL, Smith AC. Characterising skeletal muscle haemoglobin saturation during exercise using near-infrared spectroscopy in chronic kidney disease. Clin Exp Nephrol. 2019 Jan;23(1):32-42.

89 Kmentova T, Valerianova A, Kovarova L, Lachmanova J, Hladinova Z, Malik J. Decrease of muscle strength in vascular access hand due to silent ischaemia. J Vasc Access. 2018 Nov; 19(6):573-7.

90 Miyazawa $\mathrm{H}$, Ookawara S, Ito K, Yanai K, Ishii $\mathrm{H}$, Kitano T, et al. Factors associating with oxygenation of lower-limb muscle tissue in hemodialysis patients. World J Nephrol. 2016 Nov;5(6):524-30.

91 De Blasi RA, Luciani R, Punzo G, Arcioni R, Romano R, Boezi M, et al. Microcirculatory changes and skeletal muscle oxygenation measured at rest by non-infrared spectroscopy in patients with and without diabetes undergoing haemodialysis. Crit Care. 2009; 13(Suppl 5):S9.

92 Ito K, Ookawara S, Ueda Y, Goto S, Miyazawa $\mathrm{H}$, Yamada H, et al. Factors affecting cerebral oxygenation in hemodialysis patients: cerebral oxygenation associates with $\mathrm{pH}$, hemodialysis duration, serum albumin concentration, and diabetes mellitus. PLoS One. 2015; 10(2):e0117474.
93 Valerianova A, Lachmanova J, Kovarova L, Kmentova T, Bartkova M, Malik J. Factors responsible for cerebral hypoxia in hemodialysis population. Physiol Res. 2019 29; 68(4):651-8.

94 Ito K, Ookawara S, Ueda Y, Miyazawa H, Kofuji M, Hayasaka $\mathrm{H}$, et al. Changes in cerebral oxygenation associated with intradialytic blood transfusion in patients with severe anemia undergoing hemodialysis. Nephron Extra. 2017 Apr;7(1):42-51.

95 Minato S, Ookawara S, Ito K, Miyazawa H, Hayasaka H, Kofuji M, et al. Differences in cerebral and hepatic oxygenation in response to intradialytic blood transfusion in patients undergoing hemodialysis. J Artif Organs. 2019 Dec;22(4):316-23.

96 Papadopoulos G, Dounousi E, Papathanasiou A, Papathanakos G, Tzimas P. Cerebral oximetry values in dialyzed surgical patients: a comparison between hemodialysis and peritoneal dialysis. Ren Fail. 2013 Jul;35(6): 855-9.

97 Matsukawa S, Hamada M, Mizota T. Low preoperative regional cerebral oxygen saturation in hemodialysis patients. JA Clin Rep. 2017;3(1):13.

98 Ito K, Ookawara S, Okochi T, Ueda Y, Kofuji $\mathrm{M}$, Hayasaka $\mathrm{H}$, et al. Deterioration of cerebral oxygenation by aortic arch calcification progression in patients undergoing hemodialysis: a cross-sectional study. Biomed Res Int. 2017;2017:2852514.

99 Malik J, Kudlicka J, Lachmanova J, Valerianova A, Rocinova K, Bartkova M, et al. Tissue ischemia worsens during hemodialysis in end-stage renal disease patients. J Vasc Access. 2017 Jan;18(1):47-51.

100 MacEwen C, Sutherland S, Daly J, Pugh C, Tarassenko L. Relationship between hypotension and cerebral ischemia during hemodialysis. J Am Soc Nephrol. 2017 Aug;28(8): 2511-20.

101 Prohovnik I, Post J, Uribarri J, Lee H, Sandu O, Langhoff E. Cerebrovascular effects of hemodialysis in chronic kidney disease. J Cereb Blood Flow Metab. 2007 Nov;27(11): 1861-9.

102 Kielstein JT, Fliser D. The past, presence and future of ADMA in nephrology. Nephrol Ther. 2007 Apr;3(2):47-54.

103 Yilmaz MI, Saglam M, Caglar K, Cakir E, Sonmez A, Ozgurtas T, et al. The determinants of endothelial dysfunction in CKD: oxidative stress and asymmetric dimethylarginine. Am J Kidney Dis. 2006 Jan;47(1):42-50.

104 Ravani P, Tripepi G, Malberti F, Testa S, Mallamaci F, Zoccali C. Asymmetrical dimethylarginine predicts progression to dialysis and death in patients with chronic kidney disease: a competing risks modeling approach. J Am Soc Nephrol. 2005 Aug;16(8): 2449-55.

105 Raptis V, Georgianos PI, Sarafidis PA, Sioulis A, Makedou K, Makedou A, et al. Elevated asymmetric dimethylarginine is associated with oxidant stress aggravation in pa- tients with early stage autosomal dominant polycystic kidney disease. Kidney Blood Press Res. 2013;38(1):72-82.

106 Wang F, Xiong R, Feng S, Lu X, Li H, Wang S. Association of circulating levels of ADMA with carotid intima-media thickness in patients with CKD: a systematic review and meta-analysis. Kidney Blood Press Res. 2018;43(1):25-33.

107 Kobayashi S, Oka M, Maesato K, Ikee R, Mano T, Hidekazu M, et al. Coronary artery calcification, ADMA, and insulin resistance in CKD patients. Clin J Am Soc Nephrol. 2008 Sep;3(5):1289-95.

108 Nanayakkara PW, Teerlink T, Stehouwer CD, Allajar D, Spijkerman A, Schalkwijk C, et al. Plasma asymmetric dimethylarginine (ADMA) concentration is independently associated with carotid intima-media thickness and plasma soluble vascular cell adhesion molecule-1 (sVCAM-1) concentration in patients with mild-to-moderate renal failure. Kidney Int. 2005 Nov;68(5):2230-6.

109 Shi B, Ni Z, Zhou W, Yu Z, Gu L, Mou S, et al. Circulating levels of asymmetric dimethylarginine are an independent risk factor for left ventricular hypertrophy and predict cardiovascular events in pre-dialysis patients with chronic kidney disease. Eur J Intern Med. 2010 Oct;21(5):444-8.

110 Yilmaz MI, Sonmez A, Saglam M, Qureshi AR, Carrero JJ, Caglar K, et al. ADMA levels correlate with proteinuria, secondary amyloidosis, and endothelial dysfunction. J Am Soc Nephrol. 2008 Feb;19(2):388-95.

111 Caglar K, Yilmaz MI, Sonmez A, Cakir E, Kaya A, Acikel C, et al. ADMA, proteinuria, and insulin resistance in non-diabetic stage I chronic kidney disease. Kidney Int. 2006 Aug;70(4):781-7.

112 Zoccali C, Bode-Böger S, Mallamaci F, Benedetto F, Tripepi G, Malatino L, et al. Plasma concentration of asymmetrical dimethylarginine and mortality in patients with endstage renal disease: a prospective study. Lancet. 2001 Dec;358(9299):2113-7.

113 Kanbay M, Afsar B, Siriopol D, Unal HU, Karaman M, Saglam M, et al. Relevance of uric acid and asymmetric dimethylarginine for modeling cardiovascular risk prediction in chronic kidney disease patients. Int Urol Nephrol. 2016 Jul;48(7):1129-36.

114 Lu TM, Chung MY, Lin CC, Hsu CP, Lin SJ. Asymmetric dimethylarginine and clinical outcomes in chronic kidney disease. Clin J Am Soc Nephrol. 2011 Jul;6(7):1566-72.

115 Young JM, Terrin N, Wang X, Greene T, Beck GJ, Kusek JW, et al. Asymmetric dimethylarginine and mortality in stages 3 to 4 chronic kidney disease. Clin J Am Soc Nephrol. 2009 Jun;4(6):1115-20.

116 Mallamaci F, Tripepi G, Maas R, Malatino L, Böger R, Zoccali C. Analysis of the relationship between norepinephrine and asymmetric dimethyl arginine levels among patients with end-stage renal disease. J Am Soc Nephrol. 2004 Feb;15(2):435-41. 
117 Yilmaz MI, Saglam M, Caglar K, Cakir E, Ozgurtas T, Sonmez A, et al. Endothelial functions improve with decrease in asymmetric dimethylarginine (ADMA) levels after renal transplantation. Transplantation. 2005 Dec;80(12):1660-6.

118 Abedini S, Meinitzer A, Holme I, März W, Weihrauch G, Fellstrøm B, et al. Asymmetrical dimethylarginine is associated with renal and cardiovascular outcomes and all-cause mortality in renal transplant recipients. Kidney Int. 2010 Jan;77(1):44-50.

119 Roumeliotis S, Mallamaci F, Zoccali C. Endothelial dysfunction in chronic kidney disease, from biology to clinical outcomes: a 2020 update. J Clin Med. 2020 Jul;9(8):2359.

120 Blann AD. A reliable marker of vascular function: Does it exist? Trends Cardiovasc Med. 2015 Oct;25(7):588-91.

121 Feng YM, Thijs L, Zhang ZY, Yang WY, Huang QF, Wei FF, et al. Glomerular function in relation to circulating adhesion molecules and inflammation markers in a general population. Nephrol Dial Transplant. 2018 Mar 1;33(3):426-35.

122 Stam F, van Guldener C, Schalkwijk CG, ter Wee PM, Donker AJ, Stehouwer CD. Impaired renal function is associated with markers of endothelial dysfunction and increased inflammatory activity. Nephrol Dial Transplant. 2003 May;18(5):892-8.

123 Vaccaro F, Mulè G, Cottone S, Soresi M, Giannitrapani L, Vadalà $\mathrm{A}$, et al. Circulating levels of adhesion molecules in chronic kidney disease correlate with the stage of renal disease and with C-reactive protein. Arch Med Res. 2007 Jul;38(5):534-8.

124 Liakopoulos V, Eleftheriadis T, Kyropoulos T, Voliotis G, Potamianos S, Zengos N, et al. Hemodialysis procedure does not affect the levels of sICAM- 1 and SVCAM- 1 in patients with end stage renal disease. Ren Fail. 2005; 27(3):315-21.

125 van Gennip ACE, Broers NJH, Meulen KJT, Canaud B, Christiaans MHL, Cornelis T, et al. Endothelial dysfunction and low-grade inflammation in the transition to renal replacement therapy. PLoS One. 2019;14(9): e0222547.

126 Ioannou K, Stel VS, Dounousi E, Jager KJ, Papagianni A, Pappas K, et al. Inflammation, endothelial dysfunction and increased left ventricular mass in chronic kidney disease (CKD) patients: a longitudinal study. PLoS One. 2015;10(9):e0138461.

127 Malatino LS, Stancanelli B, Cataliotti A, Bellanuova I, Fatuzzo P, Rapisarda F, et al. Circulating E-selectin as a risk marker in patients with end-stage renal disease. J Intern Med. 2007 Oct;262(4):479-87.
128 Testa A, Benedetto FA, Spoto B, Pisano A, Tripepi G, Mallamaci F, et al. The E-selectin gene polymorphism and carotid atherosclerosis in end-stage renal disease. Nephrol Dial Transplant. 2006 Jul;21(7):1921-6.

129 Stancanelli B, Malatino LS, Cataliotti A, Bellanuova I, Mallamaci F, Tripepi G, et al. Soluble E-selectin is an inverse and independent predictor of left ventricular wall thickness in end-stage renal disease patients. Nephron Clin Pract. 2010;114(1):c74-80.

130 Mitsides N, Alsehli FMS, Mc Hough D, Shalamanova L, Wilkinson F, Alderdice J, et al. Salt and water retention is associated with microinflammation and endothelial injury in chronic kidney disease. Nephron. 2019; 143(4):234-42.

131 Boulanger CM, Amabile N, Guérin AP, Pannier B, Leroyer AS, Mallat $\mathrm{CN}$, et al. In vivo shear stress determines circulating levels of endothelial microparticles in end-stage renal disease. Hypertension. 2007 Apr;49(4): 902-8.

132 Jalal D, Renner B, Laskowski J, Stites E, Cooper J, Valente K, et al. Endothelial microparticles and systemic complement activation in patients with chronic kidney disease. J Am Heart Assoc. 2018 13;7(14):e007818.

133 Faure V, Dou L, Sabatier F, Cerini C, Sampol $\mathrm{J}$, Berland $\mathrm{Y}$, et al. Elevation of circulating endothelial microparticles in patients with chronic renal failure. J Thromb Haemost. 2006 Mar;4(3):566-73.

134 Merino A, Portolés J, Selgas R, Ojeda R, Buendia P, Ocaña J, et al. Effect of different dialysis modalities on microinflammatory status and endothelial damage. Clin J Am Soc Nephrol. 2010 Feb;5(2):227-34.

135 Amabile N, Guérin AP, Leroyer A, Mallat Z, Nguyen C, Boddaert J, et al. Circulating endothelial microparticles are associated with vascular dysfunction in patients with endstage renal failure. J Am Soc Nephrol. 2005 Nov;16(11):3381-8.

136 Amabile N, Guérin AP, Tedgui A, Boulanger $\mathrm{CM}$, London GM. Predictive value of circulating endothelial microparticles for cardiovascular mortality in end-stage renal failure: a pilot study. Nephrol Dial Transplant. 2012 May;27(5):1873-80.

137 Dursun I, Poyrazoglu HM, Gunduz Z, Ulger H, Yykylmaz A, Dusunsel R, et al. The relationship between circulating endothelial microparticles and arterial stiffness and atherosclerosis in children with chronic kidney disease. Nephrol Dial Transplant. 2009 Aug; 24(8):2511-8
138 Carmona A, Agüera ML, Luna-Ruiz C, Buendía P, Calleros L, García-Jerez A, et al. Markers of endothelial damage in patients with chronic kidney disease on hemodialysis. Am J Physiol Renal Physiol. 2017 Apr 1; 312(4):F673-81.

139 Green D, Skeoch S, Alexander MY, Kalra PA, Parker B. The association of baseline and longitudinal change in endothelial microparticle count with mortality in chronic kidney disease. Nephron. 2017;135(4):25260.

140 Padberg JS, Wiesinger A, di Marco GS, Reuter S, Grabner A, Kentrup D, et al. Damage of the endothelial glycocalyx in chronic kidney disease. Atherosclerosis. 2014 Jun; 234(2):335-43.

141 Koch J, Idzerda NMA, Dam W, Assa S, Franssen CFM, van den Born J. Plasma syndecan- 1 in hemodialysis patients associates with survival and lower markers of volume status. Am J Physiol Renal Physiol. 2019 Jan 1;316(1):F121-7.

142 Yilmaz MI, Sonmez A, Ortiz A, Saglam M, Kilic S, Eyileten T, et al. Soluble TWEAK and PTX3 in nondialysis CKD patients: impact on endothelial dysfunction and cardiovascular outcomes. Clin J Am Soc Nephrol. 2011 Apr;6(4):785-92.

143 Nishi K, Imamura T, Kitamura K, Ogawa T, Fujimoto S, Kakitsubata Y, et al. Associations of plasma pentraxin 3 and monocyte chemoattractant protein-1 concentrations with cardiovascular disease in patients with chronic kidney disease. Ren Fail. 2011;33(4): 398-404.

144 Vaux EC, Taylor DJ, Altmann P, Rajagopalan B, Graham K, Cooper R, et al. Effects of carnitine supplementation on muscle metabolism by the use of magnetic resonance spectroscopy and near-infrared spectroscopy in end-stage renal disease. Nephron Clin Pract. 2004;97(2):c41-8.

145 Pipili C, Vasileiadis I, Grapsa E, Tripodaki ES, Ioannidou S, Papastylianou A, et al. Microcirculatory alterations during continuous renal replacement therapy in ICU: a novel view on the "dialysis trauma" concept. Microvasc Res. 2016;103:14-8.

146 Ookawara S, Ito K, Ueda Y, Miyazawa H, Hayasaka H, Kofuji M, et al. Differences in tissue oxygenation and changes in total hemoglobin signal strength in the brain, liver, and lower-limb muscle during hemodialysis. J Artif Organs. 2018;21(1):86-93. 